NBER WORKING PAPER SERIES

\title{
DO LIQUIDATION VALUES AFFECT FINANCIAL CONTRACTS? EVIDENCE FROM COMMERCIAL LOAN CONTRACTS AND ZONING REGULATION
}

\author{
Efraim Benmelech \\ Mark J. Garmaise \\ Tobias J. Moskowitz \\ Working Paper 11004 \\ http://www.nber.org/papers/w11004 \\ NATIONAL BUREAU OF ECONOMIC RESEARCH \\ 1050 Massachusetts Avenue \\ Cambridge, MA 02138 \\ December 2004
}

We have benefitted from the suggestions and comments of an anonymous referee, Tony Bernardo, Marianne Bertrand, Lauren Cohen, Doug Diamond, Eugene Fama, Oliver Hart, John Heaton, Thomas Hubbard, Eugene Kandel, Steve Kaplan, Robert Novy-Marx, Amil Petrin, Andrei Shleifer, Jeremy Stein, Per Stromberg, Luigi Zingales, and seminar participants at the University of Chicago Finance lunch and Indiana University. Special thanks to Michael Arabe, John Edkins, and Peggy McNamara as well as COMPS.com for providing commercial real estate and zoning regulation data, to Bob Figlio, Dave Ingeneri, and CAP Index, Inc. for providing crime data, and to Joseph Gyourko for supplying us with the Wharton Land Use Control Survey. Moskowitz thanks the Center for Research in Security Prices and the James S. Kemper Foundation Research Fund for financial support. The views expressed herein are those of the author(s) and do not necessarily reflect the views of the National Bureau of Economic Research.

(C) 2004 by Efraim Benmelech, Mark J. Garmaise, and Tobias J. Moskowitz. All rights reserved. Short sections of text, not to exceed two paragraphs, may be quoted without explicit permission provided that full credit, including (C) notice, is given to the source. 
Do Liquidation Values Affect Financial Contracts? Evidence from Commercial Loan Contracts and Zoning Regulation

Efraim Benmelech, Mark J. Garmaise, and Tobias J. Moskowitz

NBER Working Paper No. 11004

December 2004

JEL No. G3, R0

\section{ABSTRACT}

We examine the impact of asset liquidation value on debt contracting using a unique set of commercial property non-recourse loan contracts. We employ commercial zoning regulation to capture the flexibility of a property's permitted uses as a measure of an asset's redeployability or value in its next best use. Within a census tract, more redeployable assets receive larger loans with longer maturities and durations, lower interest rates, and fewer creditors, controlling for the current value of the property, its type, and neighborhood. These results are consistent with incomplete contracting and transaction cost theories of liquidation value and financial structure.

Efraim Benmelech

Graduate School of Business

University of Chicago

ebenmelech@hbs.edu

Mark J. Garmaise

Anderson School

UCLA

mark.germaise@anderson.ucla.edu

Tobias Moskowitz

Graduate School of Business

University of Chicago

1101 East 58th Street

Chicago, IL 60637

and NBER

tobias.moskowitz@gsb.uchicago.edu 


\section{Introduction}

How do liquidation values affect financial contracts? An extensive theoretical literature examines this question (Williamson (1988), Harris and Raviv (1990), Aghion and Bolton (1992), Shleifer and Vishny (1992), Hart and Moore (1994), Bolton and Scharfstein (1996), and Diamond (2004)) and concludes that optimal debt policy critically depends on how costly it is for creditors to seize and liquidate assets. However, empirical evidence on this question is scarce, due to the difficulty in obtaining a measure of an asset's liquidation value or value in its next best use. We provide empirical evidence on the link between liquidation value and debt contracts using a unique sample of commercial property loans and variation in property zoning ordinances.

Liquidation value is of central importance for financial decisions when contracts are incomplete and transaction costs exist, as noted by Williamson (1985, 1988), Grossman and Hart (1986), and Hart and Moore (1990). In particular, debt contracts allow the creditor to seize the debtor's assets when the latter fails to make a promised payment. The liquidation value of the asset establishes the creditor's outside option and thereby determines his bargaining power relative to that of the debtor, making foreclosure threats more or less credible and affecting the incentives of both parties to invest in the enterprise. Hart (1995) emphasizes the importance of allocating control rights and seizure of assets as a credible threat in determining the financial contract between an entrepreneur and outside investors. Since the entrepreneur cannot commit to not withdraw his human capital from the project (as in Hart and Moore (1994)), or to not divert cash flows to himself (as in Hart and Moore (1989) and Aghion and Bolton (1992)), creditors will agree to lend only if the debt is secured by the project's assets and default triggers its liquidation.

Despite the broad implications of these theories and their appealing intuitions, supporting evidence is sparse. Testing the theories requires data on both debt contracts and the characteristics of the assets that are used to secure the debt. In particular, the econometrician must observe the liquidation value of the asset, but it is difficult to ascertain ex ante, when the parties enter the debt contract, what the proceeds from selling the asset to the next user might be. As a proxy for the ex ante value of the asset in its next best use, we employ property-specific zoning assignments to capture micro-level variation in liquidation values.

The real estate market is a natural candidate for testing financial contracting from an incomplete contracting perspective. First, commercial property loans are secured, emphasizing the importance 
of liquidation values for financial contracting. Second, the loans are non-recourse, thus providing a set of project-specific financings and characteristics consistent with the inalienability of human capital described by Hart and Moore (1994) and other models. Finally, the real estate market offers a potential measure of an asset's liquidation value through zoning ordinances which govern the permitted uses of a property.

This empirical approach is motivated by Shleifer and Vishny's (1992) hypothesis that regulation determines the number of potential buyers in the market. A broader set of buyers can potentially raise the liquidation value of an asset. Since zoning regulations determine the set of uses to which a property may be put, we exploit variation in zoning at the property level to generate a measure of liquidation value. We consider the intensity and scope with which one can use a property within its broad zoning category and within its local zoning jurisdiction. This restriction governs the set of potential alternative uses for an asset. Properties with more allowable uses should have a greater number of potential buyers, all else equal, and therefore a higher value in the event of liquidation. This is a measure of the asset's redeployability in the sense of Williamson (1988) and we adopt the same terminology.

We recognize that the current value of the asset is also likely to be affected by redeployability and, more specifically, zoning, which in turn may be affected by local market unobservables. However, we argue that endogeneity concerns over the price-zoning relation (Glaeser and Gyourko (2002) and McMillen and McDonald (2002)) are less relevant for our study of debt contracts for several reasons. First, the potential endogeneity of zoning typically refers to the relation between local market conditions and the local zoning code at the jurisdiction or city level. We examine property-specific zoning assignments within a neighborhood, controlling for local economic variables. We also employ property type, year, and general zoning category fixed effects. In many of our tests we employ census tract level fixed effects to difference out the unobservables. A census tract typically covers between 2,500 and 8,000 persons or about a 4 square block area in most cities, and is designed to be homogeneous with respect to population characteristics, economic status, and living conditions (source: U.S. Census Bureau). Since zoning regulation is set at a much broader level, either city or municipality, census tract fixed effects eliminate any unobservables possibly affecting the local zoning code. Fixed effects at a level this fine also eliminate the influence of any plausible unobserved neighborhood variable such as local "quality" or degree of bank redlining. In addition, because census tracts are designed to capture population and economic homogeneity, 
using tract fixed effects also controls for the characteristics of buyers and sellers at this level. Hence, tract fixed effects should alleviate endogeneity concerns over the relation between zoning and local unobservables. Second, we focus on the characteristics of the debt contracts controlling for the current value of the property. The current value of the property captures all of the relevant local and other variables that affect value under its current use. By controlling for current value we attempt to isolate the component of redeployability related to its secondary or liquidation value. This likely understates the impact of our measure. Consistent with this, results are magnified when removing controls for current value.

We find that, controlling for current value, property type, general zoning type, year, and census tract fixed effects, greater redeployability is associated with greater loan size, lower interest rates, longer maturity and longer duration debt, and fewer creditors. These results highlight the economic importance of liquidation value and provide support for incomplete contracting and transaction cost theories for financial policy. Within a census tract, property type, and general zoning category, and controlling for current price, moving from the least to the average (most) zoning flexibility lowers the interest loan rate by 27 (57) basis points per annum, increases the loan's size relative to the value of the property by 5.9 (12.6) percentage points, lengthens the loan's maturity by 2.8 (6.1) years, increases the loan's duration by 0.17 (0.37) years, and decreases the probability of borrowing from multiple lenders by 3.6 (7.6) percentage points.

We also find that these effects are magnified in districts in which survey evidence (from the Wharton Land Use Control Survey) suggests zoning rules are administered more strictly and in jurisdictions with stronger overall law enforcement. In areas where zoning is more difficult to change and more strongly enforced and adhered to, our redeployability measure has an even greater impact on the terms of loan contracts. Likewise, for individual properties that appear more difficult to obtain zoning changes, such as historic properties or properties zoned similar to their neighbors, we find the effects of our redeployability measure on debt contracts to be stronger. Finally, we also find that interactions between redeployability and measures of local market liquidity, such as the competitiveness of the local brokerage market or survey responses on demand for land uses relative to the supply of land zoned for those uses, enhance the importance of redeployability on debt terms.

For robustness, we also employ other, perhaps more endogenous, measures of liquidation value such as the competitiveness of the local property brokerage market, location in an "historical" zoning district, the volume of property sales in an area, the similarity of a property's zoning to 
its neighbors, population density, and property age. The results using these proxies generally support our primary findings: higher liquidation value decreases interest rates and the probability of multiple lenders and increases the probability of obtaining a loan, its relative size, maturity, and duration.

Finally, we also examine the relation between our redeployability measure and other outcome variables associated with liquidation values. For instance, we find that more redeployable properties do indeed enjoy higher market prices and that sellers of more redeployable properties are less likely to hire professional brokers to market their properties. While we interpret these results with caution due to greater endogeneity concerns, particularly with respect to price, these findings are consistent with our flexibility of zoning measure capturing liquidation value.

Earlier empirical studies analyze some of the implications of incomplete contracting for financial structure, but typically do not focus on liquidation value, which plays a prominent role in the theory. Baker and Hubbard $(2001,2003)$ provide some evidence on the relation between asset ownership and contractibility, but do not examine financial contracts or redeployability. Kaplan and Stromberg (2002) show that the structure of many venture capital contracts is consistent with the allocation of control rights in incomplete contracts, but they too do not examine the role of liquidation value. There is also little direct evidence on the importance of transaction costs to capital structure (Gilson (1997)).

Previous research has examined the existence of inefficient liquidation or "fire sales" (Pulvino (1998, 1999), Stromberg (2000)), but not the interplay between ex ante liquidation value and financial structure at the time the contract is set. Other studies examine the relation between balance-sheet figures such as tangibility (e.g., the ratio of fixed assets to total assets) and capital structure, (Braun (2003), Harris and Raviv (1991), and Rajan and Zingales (1995)), but it is not clear that such proxies capture liquidation value or the asset value in its next best use. Benmelech (2003) analyzes the relation between asset salability and capital structure among $19^{\text {th }}$ century American railroads. Using variation in the track gauge across railroads, he finds that railroads with more redeployable cars and that conformed to the standard gauge had longer maturity debt, complementing our evidence. He finds, however, no relation between asset salability and leverage.

In addition, little evidence on the relation between the number of creditors and liquidation values exists. Several recent papers study the relation between cross-country differences in creditors protection and the number of banking relationships (Ongena and Smith (2000), Esty and Meg- 
ginson (2003), and Detragiache, Garella, and Guiso (2000)). We provide micro-level evidence to complement these cross-country comparisons of creditor protection and legal systems.

The rest of the paper is organized as follows. Section I summarizes theoretical predictions on the relation between liquidation value and financial contracting. Section II details the commercial loan data and local zoning regulations used in our analysis and describes the empirical strategy we employ to measure changes in liquidation value through zoning laws. Section III presents our empirical results on the effect of asset liquidation value through zoning on debt contracts. Section IV examines the impact of other measures of asset liquidation value on loan terms and Section $\mathrm{V}$ presents additional evidence relating liquidation values to prices and broker activity. Finally, Section VI concludes the paper.

\section{Theoretical Predictions}

In several influential theories of financial contracting, asset liquidation value is a central determinant of the optimal capital structure used to finance an investment. In this section we provide a brief overview of these theories, detail their predictions, and describe how these predictions fit our sample of commercial loan contracts.

\section{A. Liquidation value and financial contracts}

Williamson's (1988) transaction cost approach emphasizes that asset characteristics are a critical feature in determining the optimal financing of a project. In particular, debt is an unforgiving, rules-based claim that will require liquidation in adverse states. Assets that are redeployable (i.e., assets that are not specialized and that have valuable other uses) will be particularly suited to debt financing. Shleifer and Vishny (1992) focus instead on the effects of asset illiquidity. In their industry-equilibrium model, assets with few potential buyers, or with potential buyers who are likely to be financially constrained when a firm attempts liquidation, will be poor candidates for debt finance, since liquidation is likely to yield a low price.

Harris and Raviv (1990) analyze the information effects of debt. Debt can facilitate efficient liquidation since managers who miss payments are forced to reveal information to creditors, and in default creditors will choose to liquidate the firm if that yields more than a reorganization. Managers are assumed to always prefer to avoid liquidation. In Hart and Moore (1994), contractual incompleteness and the non-verifiability of cash flows limit the ability of creditors to make claims 
on the firm. Creditors do retain the option, however, to liquidate the assets of the firm. The greater the liquidation value of the assets, the more creditors are willing to lend, since they are assured of a higher payment. Bolton and Scharfstein (1996) consider the optimal number of creditors. They argue that borrowing from multiple creditors can make default costly, which disciplines managers but may lead to inefficient outcomes when default is involuntary. Bolton and Scharfstein (1996) show that borrowing from one creditor is optimal when liquidation values are high since the absolute costs of inefficient liquidation are high in that case. When liquidation values are low, multiple creditors provide discipline at little cost in forgone liquidation payments. Diamond (2004) makes a similar prediction when lender intervention is costly.

The concept of liquidation value used in the Harris and Raviv (1990), Hart and Moore (1994), and Bolton and Scharfstein (1996) models is fairly general: an asset's liquidation value is the amount that creditors can expect to receive if they seize the asset from managers and sell it on the open market. Williamson (1988) and Shleifer and Vishny (1992) consider two different components of liquidation value. Williamson (1988) analyzes asset redeployability, while Shleifer and Vishny (1992) study asset illiquidity. In our empirical work we propose a specific proxy for redeployability, using zoning regulations, and examine its impact on financial contracts. For robustness, we also employ other proxies for liquidity and find similar effects.

The models discussed above yield the following empirical predictions:

Prediction 1. Debt levels increase in asset liquidation value.

This is a general prediction emerging from Williamson (1988), Shleifer and Vishny (1992), Harris and Raviv (1990), and Hart and Moore (1994). Debt triggers liquidation in some states in all these models, and the benefits of debt are tied to the efficiency of liquidation.

Prediction 1b. The promised debt yield decreases in asset liquidation value, controlling for the debt level.

Following Prediction 1, increased liquidation value lowers the cost of liquidation. In equilibrium, lenders therefore charge lower interest rates on loans made on assets with higher liquidation value, controlling for the debt level. This is in part why optimal debt levels also rise (Prediction 1).

Prediction 2. Debt maturity increases in asset liquidation value.

Prediction 2 emerges from Hart and Moore (1994) and from Shleifer and Vishny (1992). Hart 
and Moore (1994) argue that a higher profile of liquidation values over time increases the asset's durability and makes longer maturity debt feasible. Shleifer and Vishny (1992) analyze the trade-off between the benefit of debt overhang in constraining management and liquidation costs. Benmelech (2003) shows that higher liquidation values make overhang (long-term) debt more attractive. Since debt overhang limits managers' ability to bypass short-term debt constraints, long-term debt capacity increases with liquidation value. Thus, Shleifer and Vishny (1992) predict an increase in debt maturity with liquidation value. Although some of these theories only consider zero-coupon debt, a reasonable extrapolation yields the implication that debt duration will also increase in liquidation value.

Prediction 3. Firms borrow from multiple creditors when liquidation value is low and from a single creditor when liquidation value is high.

This is a prediction of Bolton and Scharfstein (1996) and Diamond (2004). Multiple creditors provide discipline at the cost of inefficient liquidation. ${ }^{1}$

Prediction 4. The promised debt yield is increasing in asset liquidation value.

An increase in the liquidation value of the asset raises the optimal debt level but also provides a greater payment to creditors. The net effect on promised debt yields is analytically ambiguous, but in numerical results Harris and Raviv (1990) show that firms with higher liquidation values consistently have higher debt yields. Prediction $1 \mathrm{~b}$ shows that when controlling for the debt level of the firm, by contrast, higher liquidation values should be associated with lower promised yields, since creditors can expect a higher payment in the case of default.

Prediction 5. The market value of the asset is increasing in its liquidation value.

Since the liquidation value of the asset is a component of its overall value, increasing the liquidation value increases total asset value. This natural prediction comes from Harris and Raviv (1990). In addition, Shleifer and Vishny (1992) make a prediction about the existence of asset "fire sales" in liquidation, which is also consistent with market values increasing with liquidation values.

\footnotetext{
${ }^{1}$ A distinction between Bolton and Scharfstein (1996) and Diamond (2004) can be made regarding the priority or seniority of creditors. In Diamond's (2004) model, externalities among creditors drive this prediction, where priority can be viewed as an externality. In Bolton and Scharfstein (1996) lenders have the same priority. Unfortunately, our data do not allow us to distinguish whether multiple creditors or priority among creditors is more important since second lenders uniformly have lower priority claim on the assets in our sample.
} 


\section{B. Application to commercial real assets}

In order to test these implications we employ a unique dataset of commercial property transactions and financial contracts and use property-specific zoning assignments to capture variation in liquidation value. Some discussion of the relation between the data and the models is in order.

Commercial property loans are secured, highlighting the potential importance of liquidation value, and are typically non-recourse (Stein (1997)). The lender may only pursue the collateral, in this case the property, and not any other assets of the borrower in case of default. The nonrecourse feature of these loans therefore allows for a clean analysis of project-specific financing and its relation to the asset's characteristics, namely its liquidation value. Many of the aforementioned models are motivated or can be interpreted in this spirit. Indeed, the non-recourse nature of the loans makes the value of collateral critical for financial contracting, and therefore well-suited to testing the theories. In addition, examining variation in financial contracts within a particular asset class also helps to reduce confounding influences such as control issues, cash flow rights, risk, industry competitiveness, etc. that may arise when examining contracts across vastly different assets, projects, or investments. Finally, we will argue in the next section that the use of propertyspecific zoning assignments within a neighborhood can capture micro-level variation in liquidation values used to test the predictions of these models.

\section{Data and Empirical Strategy}

We briefly describe the data sources used in the paper and our identification strategy for capturing asset liquidation value.

\section{A. Transaction and financing level data of commercial real assets}

Our sample consists of commercial real asset transactions drawn from across the U.S. over the period January 1, 1992 to March 30, 1999 from COMPS.com, a leading provider of commercial real estate sales data. COMPS collects data on commercial transactions by contacting buyers, sellers, and brokers, and then confirms their reports with each of these parties. Garmaise and Moskowitz (2003, 2004a) provide an extensive description of the COMPS database and detailed summary statistics. There are 14,159 commercial transactions reported over our sample period that contain recorded sale price, loan terms, information on lenders, identities of principals, property location, and zoning 
designation. The data span 11 states: California, Nevada, Oregon, Massachusetts, Maryland, Virginia, Texas, Georgia, New York, Illinois, and Colorado, plus the District of Columbia.

COMPS records for each property transaction the sale price, specific zoning designation (described below), and terms of the loan contract at the time of sale. Hence, we see the property's market value, zoning designation, and loan terms at the time when the loan contract is negotiated. As documented by Garmaise and Moskowitz (2003, 2004a) debt financing dominates the financial structure of commercial properties, comprising $71 \%$ of the property's value on average. In addition to cash, the remaining source of funds typically comes from the seller, known as vendor-to-buyer financing, in the form of a debt contract. These occur in about $13 \%$ of transactions and are typically junior to bank loans. For more discussion of the role of seller financing and the tradeoff with bank debt, see Garmaise and Moskowitz (2004a). Properties can have first and second trust deeds (mortgages), where the latter has lower priority claim on the real asset. We use the presence of second trusts from another lender to capture multiple creditors in our analysis.

Finally, in only $2 \%$ of deals does a buyer assume an existing mortgage from a bank rather than negotiate a new loan. We focus on the terms of new loan contracts, including interest rates and maturity, and the size and presence of bank debt.

COMPS also provides eight digit latitude and longitude coordinates of the property's location (accurate to within 10 meters). From these, we construct characteristics of the local market in which each property resides using Census data, survey data from the Wharton Land Use Control Survey, and crime rate data.

Table 1 reports summary statistics on the properties in our sample. Panel A shows that the average sale price is $\$ 2.4$ million, though values range from $\$ 20,000$ to $\$ 750$ million. ${ }^{2}$ The average loan-to-value ratio (when debt is present) is $71 \%$, with $71 \%$ of properties having at least some debt and $12 \%$ having more than one creditor. Median loan maturity is 15 years and interest rates average 8.3 (and range from 5 to 11.75) percent per annum. Other recorded details of the loan contract are whether the loan rate is floating or fixed, whether amortized and the length of amortization, and whether the loan was backed by the Small Business Administration (occurring only 1.3 percent of the time). We will control for these features in our analysis. We also use the reported interest rate $(r)$, loan maturity $(m)$ and amortization period $(a)$ to estimate the duration of the loan. Assuming

\footnotetext{
${ }^{2}$ Larger portfolios of properties such as REITS comprise only 42 transactions total, which is less than 0.2 percent of the sample.
} 
that the debt coupons are paid annually and that there is one final balloon payment at maturity, the duration is given by

$$
\text { Duration }=\frac{r+1-\frac{((m-1) r+r+1)}{(1+r)^{m-1}}}{r\left(1-\frac{1}{(1+r)^{a}}\right)}+m\left(\frac{\frac{1}{(1+r)^{m-1}}-\frac{1}{(1+r)^{a}}}{1-\frac{1}{(1+r)^{a}}}\right) .
$$

The median loan duration is 6.8 years. The mean age of our properties is just under 29 years, but ranges from zero to 200 years. Overall, the properties in the data set are relatively small and old compared with institutional quality real estate. (See, for example, Titman, Tompaidis, and Tsyplakov, 2004.) These properties are particularly appropriate for tests of the role of liquidation value since the real option to liquidate the asset (for example, by knocking it down and constructing something new) is more important for older and lower quality buildings than it is for new, highquality structures.

\section{B. Zoning designations}

We see 161 unique zoning designations among our properties. Zoning regulations are controlled by local units of the government and are designed to manage the physical development of land and the uses to which each individual property may be put. Zoning rules typically specify the areas in which residential, commercial, industrial, or recreational activities may take place. In addition to restricting the permitted uses that can be made of land and buildings, zoning laws also regulate property characteristics. For example, they may limit the permitted size of the building relative to the size of the lot, the number of dwelling units permitted on the lot, the maximum height and number of stories, or the industrial nature and intensity of use of the property. Since zoning is a local affair, set at the county, city, or municipality level, its ordinances and classifications vary from place to place. Glaeser and Gyourko (2002) discuss the determination of zoning in an area and its conformity to local market conditions. However, our zoning tests will make use of variation in zoning designations within a given jurisdiction, and hence control for local market conditions potentially affecting the zoning code.

Zoning definitions are typically nested and classified along two facets. The first dimension spans the breadth of permitted uses. The most common categories of this dimension in urban areas are: business, commercial, manufacturing, commercial-manufacturing, and residential. Other categories include: waterfront, organizations and non-for-profits, and historical and cultural preservation 
districts. Panel A of Table 1 reports loan and property characteristics across these categories. The second dimension of zoning determines the intensity and scope of the allowable use of the property within its broad category. It is typically denoted by a numeric scale, while an alphabetic modifier describes the zoning category. Table A1 provides an example of the residential zoning codes in New York city. We term the numerical intensity the "within zoning value." Higher values indicate broader scopes of allowable uses within its general category. The last column of Table 1 Panel A reports the number of unique zoning codes within each broad zoning category. We will exploit the nested nature of the zoning code for our measure of redeployability within a general zoning category and within a local zoning jurisdiction and census tract, described in the next subsection.

Panel B of Table 1 reports the distribution of property types, grouped into 10 mutually exclusive types: retail, commercial, industrial, apartment, mobile home park, special, residential land, industrial land, office, and hotel, across the eight broad zoning categories. As Panel B indicates, many different property types are represented in each broad zoning category, indicating multiple uses of properties. Panel $\mathrm{C}$ reports loan and price information across property types. We will control for both property type and general zoning category in our analysis thereby defining our liquidation value measure within type and zoning category.

\section{Using zoning regulations to measure liquidation values}

Testing the theoretical predictions discussed in Section I requires a measure of liquidation value that is both observable at the time of the loan contract determination and plausibly independent of other factors that may influence financial contracts.

\section{C.1 Measuring redeployability (through zoning)}

Using the zoning designation of each property at the time of sale, we exploit variation within an area and zoning category in terms of the flexibility of permitted uses of the property. Our proxy of liquidation value is a measure of the property's redeployability or zoning flexibility within its general zoning category. Properties with more flexible zoning designations admit more potential uses and are more redeployable. Creditors who seize a property subject to restrictive zoning will find it difficult to pursue alternative uses for the structure or land, whereas creditors who foreclose on a property that is only loosely zoned can redeploy the asset in many different ways.

Using the nested nature of zoning definitions, we construct a measure of the flexibility of use of a 
property relative to that of other properties in the same zoning category and neighborhood. More formally, for every broad zoning category, we rank properties on their second zoning dimension (the "within numeric value") governing the intensity and scope of allowable uses within the general zoning category. Higher values indicate more allowable uses (greater flexibility). To illustrate the dimensions of zoning and how we compute our measure of redeployability, consider the case of residential zoning districts in New York city.

According to the NYC Zoning handbook, there are 18 different zoning districts within the residential category. Table A1 in the appendix provides a detailed description of each of the residential zoning districts in NYC and a summary of their permitted uses. As demonstrated in Table A1, the allowable uses within the general residential zoning category are increasing with the zoning district numeric scale. For example, the R-1 zoning district requires a minimum area of 9,500 square feet for detached structures, while the R-2 (R-4) zoning district allows for a minimum lot area of 3,800 (970) square feet. Moreover, while the R-4 zoning district permits that the land will be used for semi-detached structures with a minimum area of 1,700 square feet, the R-2 zoning district allows only detached single- or two-family residences. In addition, the maximum number of dwelling units per acre in R-2 is 11, while R-4 allows for up to 45 dwelling units per acre. As this example demonstrates, the NYC R-4 zoning designation is more flexible and has more allowable uses than R-3, which has more than R-2, and which in turn has more than R-1. The higher the numeric code, the fewer constraints placed on property uses.

To construct our redeployability measure, we extract the numeric "within value" to capture redeployability within each broad zoning category. For comparison across locales and zoning category, we then scale the within zoning numeric value by the numeric value of the zoning district with maximum allowable uses within its broad category. For example, a zoning district of M-1 is first coded by a manufacturing dummy variable that is set equal to 1, and a redeployability variable within this category. If the manufacturing zoning districts for a particular locale are: M-1, M-2, M-3, and M-4 then the within redeployability value of a property zoned M-1 will equal 0.25. Furthermore, when modifiers are used in zoning districts we refine the within numeric values further such that they account for this sub-division. For example, given the following residential zoning districts: R-1, R-2A, R-2B, R-2C, and R-3, the within numeric value of R-2C will be 2.67 and its scaled value, which is our measure of redeployability, will equal $2.67 / 3.0=0.89$. Scaling the raw within zoning value for the range of allowable uses in a given area normalizes the local 
zoning assignments across jurisdictions. For property $p$ with zoning designation $A$ - $n$ in jurisdiction $j$, this is $\frac{n}{\max \left(n \in P_{(A, j)}\right)}$, where $P_{(A, j)}$ is the set of properties within jurisdiction $j$ that have the same general zoning category $A$. The local zoning jurisdiction $j$ can vary across locales, but results are robust to uniformly defining $j$ to be the zip code, 2 mile radius, 5 mile radius, county, or MSA. For convenience and uniformity we report results defining locales at the zip code level.

Our measure of redeployability arbitrarily treats each within numeric value equally. This is done for simplicity and ease of interpretability. However, it is evident from Table A1 that moving from say R-1 to R-2 is less significant than moving from R-2 to R-3 along certain dimensions. Hence, an alternative redeployability measure could attempt to account for such nonlinearities. We do not do this for several reasons. First, we do not have detailed descriptions of every single zoning ordinance along every property dimension in every city/jurisdiction. Second, any attempt to account for these nonlinearities would also be arbitrary and subjective. Third, although the linear specification we adopt likely mismeasures the true redeployability/flexibility of use of a property, thus introducing noise into our analysis, we see no reason to expect any bias in this specification that would affect any relation to loan contract terms. Finally, and most importantly, we have formally tested whether nonlinearities are important for our results using a nonparametric specification where we employ dummy variables for every unique redeployability value in our sample. For all seven of the dependent variables we examine (6 loan terms and price) nonlinear terms are rejected in favor of a linear specification. We describe these tests and their results in more detail under the robustness section of III.B.4.

Figure 1 plots the distribution of our redeployability measure across all properties in our sample. The mean (median) scaled flexibility measure is $0.51(0.50)$ with a standard deviation of 0.24 and ranges from 0.08 to 1 .

\section{C.2 Are zoning designations a useful measure of liquidation value?}

There are two concerns with our use of a property's zoning designation as a measure of liquidation value. First, there is the question of whether zoning laws are actually enforced and how easy it is to acquire a zoning variance. Second, there is the issue of endogeneity; it may be argued that zoning assignments are made ex post to conform to market conditions.

With respect to the first question, rezoning a property or obtaining a variance is typically quite difficult. While the direct costs of a rezoning application are low, usually only a few hundred dollars, 
the indirect costs can be substantial, the waiting duration lengthy, and the outcome uncertain. Some cities are reluctant to rezone properties at all. For example, the Baltimore City (which is in our sample) Department of Planning asserts that:

"The existing zoning category is presumed to be correct. Rezoning property is a significant step and must meet stringent criteria in accordance with State regulations...The goal of zoning is to insure stability and rezoning property has the potential to alter the stability of an area."

Significant zoning changes impose externalities on neighboring properties. Rezoning a block of townhouses into a ten-story building affects the value of neighboring townhouses, obstructs their view, and limits the amount of available parking in the street. Furthermore, long-term planning, development engineering, fire safety, crime, environmental issues, and preservation efforts are examples of considerations that the local authority has to take into account when deciding upon rezoning. In addition, local planning commissions usually conduct public hearings to allow interested parties to speak for or against a rezoning proposal. A protest period typically begins after the public hearing and allows involved parties to file legal protest petitions against the request. In addition, when a rezoning request is denied, some cities require a waiting period of a year before a revised application can be made. This makes clear that acquiring a zoning variance is not trivial and is likely to be quite difficult.

This issue is, in any case, an empirical one. The evidence that we find in support of the effects of zoning on debt contracts, including interest rates and number of creditors, suggests that zoning restrictions certainly do sometimes bind. Moreover, we find that these effects are magnified in districts where zoning rules are administered more strictly and where the quality of zoning enforceability is higher. Since these areas enforce zoning restrictions more tightly or make it more difficult to change, zoning will provide a better measure of liquidation value in these areas. Likewise, for individual properties that appear more difficult to obtain zoning changes, such as historically zoned properties or properties zoned similar to their neighbors, we find the effects of our redeployability measure to be stronger.

The second issue of endogeneity is taken up in the real estate literature (e.g., McMillen and McDonald (1991), Quigley and Rosenthal (2004), and Wallace (1988)), and there is evidence that 
local market conditions can affect the general zoning of an area. ${ }^{3}$ Property-specific zoning designations, relative to other properties in the same neighborhood, are less likely to be subject to this endogeneity problem, however. In particular, for many of our tests we employ census tract fixed effects to difference out the unobservables. Fixed effects at this fine a level eliminate any local neighborhood characteristics and are finer than the level at which the zoning code is being set (typically the city). In addition, we employ fixed effects for property type, year, neighborhood, and general zoning category to difference out unobservables at these levels. Finally, the primary focus of our paper is on the implications of zoning for debt structure, where we control for the current value of the property. Local debt market conditions are clearly highly uniform within neighborhoods (particularly census tracts) so the financing environment is unlikely to be driving the micro-level zoning variation we study. Moreover, by controlling for current value, we attempt to isolate the component of our redeployability measure related to liquidation value. Variables affecting value and zoning simultaneously will be captured by current value and will, therefore, if anything, understate the effect of our zoning variable on loan terms. Potential omitted variables affecting zoning and financing on a specific property within a census tract, type, year, and zoning category and controlling for current value, are difficult to envision. This suggests that zoning flexibility (relative to current value, neighborhood, and zoning category) is a reasonable measure of liquidation value.

\section{Empirical Results of Redeployability (Through Zoning)}

Using our zoning classification proxies for liquidation value, we test the predictions of the models from Section I.

\section{A. Econometric model}

Our econometric model considers the effect of our redeployability variables on the following loan characteristics: annual interest rate, frequency (i.e., whether or not a loan is granted, a binary variable), leverage (loan size divided by the sale price), loan maturity in years, loan duration in years, and presence of multiple creditors (a binary variable). The equation estimated is

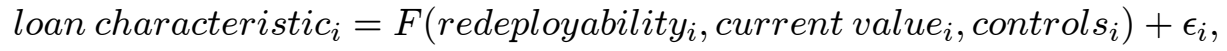

\footnotetext{
${ }^{3}$ Some useful references on the relationship between zoning and prices are Pogodzinski and Sass (1991), Pollakowski and Wachter (1990), Glaeser and Gyourko (2002), and McMillen and McDonald (2002).
} 
where controls $_{i}$ is a vector of controls containing a set of property and neighborhood attributes for asset $i$ including year, census tract, property type, and zoning category fixed effects and $\epsilon_{i}$ is an error term. We mainly estimate linear models, though other functional forms are considered for the binary dependent variables. We also test whether a non-linear functional form better describes the data and reject non-linearities in favor of a linear specification.

In advance of our discussion of the empirical results, it is worthwhile to consider the econometric issues raised by our specification in equation (2). The first point is that the current value itself may be a function of the redeployability variable; we would expect more redeployable properties to realize higher prices and, indeed, we provide evidence in favor of this hypothesis in Section V. This dependence of sale price on redeployability presents no special problem for the estimation of (2) and is accommodated by standard econometric techniques.

A second possibility is that the current value is higher when finance is provided. The buyer may be able to offer a higher price when he receives a bank loan. In this case, current value is an endogenous variable in equation (2). We are interested, however, only in the effects of redeployability (through zoning) on loan characteristics. The coefficient on redeployability remains consistent even when another regressor such as sale price is endogenous (Wooldridge, 2002). ${ }^{4}$ The coefficient on current value is not consistent in this case, but we are not interested in interpreting this coefficient.

The third, and most serious, concern is that some unobservable variable (such as bank redlining) has a simultaneous effect on loan provision, sale prices, and zoning regulations, rendering all of our variables endogenous and difficult to interpret. In all our tests, however, we measure redeployability within a zoning category and employ extensive controls including local economic variables and fixed effects for year, zoning category, and property type. We adopt two approaches to deal with potential endogeneity. The first is to use a host of local economic and social control variables measured at the zip code or census tract level to soak up endogenous correlation. In this specification we also employ a random effects model that computes standard errors that account for group-wise clustering at the zip code level. In the second approach we employ census tract fixed effects to difference out the unobservables. This will account for any unobservables, such as local "quality", at a very fine geographic level. It is unlikely that within a census tract, which consists of about a four square

\footnotetext{
${ }^{4}$ Although there may be some issues in small samples, given our relatively large sample size (as detailed in Table 1 ), it is reasonable for us to rely on asymptotic results.
} 
block area in a city, variation in some unobserved variable is jointly determining the financing environment and zoning designations. Moreover, since zoning regulation is set at the much broader city or municipality level, census tract fixed effects eliminate any unobservables possibly affecting the local zoning code.

Alternatively, unobservable variables may be property-specific, for example a characteristic of the buyer. It is highly unlikely, however, given the stability of zoning classifications, that any buyer characteristic could affect the zoning of a property at the time of sale. Moreover, because census tracts are designed to capture population and economic homogeneity, using tract fixed effects helps control for characteristics of buyers and sellers. In addition, as we argue above, controlling for the current value of the property should remove the effects of any other propertyspecific idiosyncrasies (or other local effects) that might influence both the terms of financing and the zoning classification of the property. ${ }^{5}$ Although controlling for current value likely understates the impact of redeployability, it soaks up unobservables affecting value under the property's current use.

We note here that we are essentially estimating reduced form equations for the price, quantity, and terms of the debt supplied. This is fine since we are only interested in testing the equilibrium outcomes and implications proposed by the theories in Section I. We do not show whether the results are driven by demand- or supply-side effects. While it would be interesting to differentiate between theories by distinguishing demand and supply shocks, ${ }^{6}$ our data are insufficiently rich for us to do so since they describe only equilibrium outcomes. Hence, we can only say whether the results are consistent with these theories in general, but cannot distinguish among them.

\section{B. Asset redeployability (flexibility of zoning)}

We examine the effect of our redeployability variables (i.e., greater zoning flexibility) on various loan contract terms.

\footnotetext{
${ }^{5}$ We note that previous empirical work shows that higher "quality" areas are associated with restrictive zoning (Quigley and Rosenthal (2004)), while we find, by contrast, that it is flexible zoning that predicts greater loan provision. Thus, it is difficult to argue that "quality" effects are driving our results.

${ }^{6}$ For example, in Shleifer and Vishny (1992) less debt is demanded by the asset owner as the liquidation value falls, while in Hart and Moore (1994) the creditor is willing to supply less debt for lower liquidation values.
} 


\section{B.1 Local economic and social controls}

The first column of Table 2 Panel A reports results for the regression of the loan interest rate on our redeployability measure, the current value of the property, and a set of controls. We employ the log of the sale price as a scale measure for size and use the capitalization rate on the property (current earnings divided by sale price) as a measure of current value. We discuss in the next subsection the robustness of our results to alternative specifications for current value. In addition to fixed effects for year, property type, county, and zoning category, we include the Herfindahl index of banking concentration within a 15-mile radius of the property (a measure of local bank competition for commercial loans), the log of property age, the cross-sectional variation in capitalization rates within a 15-mile radius, excluding the property itself (a measure of local price variation), characteristics of the census tract in which the property is located including levels and growth in population, per capita income, and median home value from 1990 to 2000, and the 1995 crime risk and growth in crime risk from 1990 to $1995 .^{7}$ Since crime has been linked to property values (Thaler (1978) and Garmaise and Moskowitz (2004b)) and financing (Garmaise and Moskowitz (2004b)), we add this as an additional control. In addition, for the loan rate regressions only, we also include attributes of the loan such as maturity, amortization, leverage, and dummies for floating rate loans and Small-Business-Administration-backed (SBA) loans, since these features likely affect the loan interest rate. Standard errors are calculated assuming group-wise clustering at the zip code level. ${ }^{8}$

We find that redeployability significantly decreases the interest rate charged, controlling for the debt level. A reasonable way to gauge economic significance is to consider the effect from moving from the least-flexibly-zoned designation to the average or most-flexibly-zoned within an area and

\footnotetext{
${ }^{7}$ Crime risk data come from CAP Index, Inc., who computes the crime score index for a particular location by combining geographic, economic, and population data with local police, FBI Uniform Crime Reports, victim, and loss reports. The index comprises the seven part one offenses listed by the FBI: homicide, rape, aggravated assault, robbery, burglary, larceny, and motor vehicle theft. CAP Index supplies crime scores to businesses looking to relocate or banks seeking automated teller machine locations. We match each property with the crime score index for its latitude and longitude coordinates, obtaining a property specific crime score, rather than a county average or coarser crime rate (see Garmaise and Moskowitz (2004b) for further discussion). The crime scores measure the probability that a certain crime will be committed in a given location relative to the county level of crime. CAP Index provided crime scores at three points in time: 1990, 1995, and 2000.

${ }^{8} \mathrm{We}$ have also clustered standard errors at the census tract level and obtained nearly identical results. In addition, clustering by year and removing year fixed effects resulted in even stronger results. Hence, cross-correlation in the residuals appears to be driven more by correlation within geographic area rather than year. Therefore, to be conservative, we assume group-wise clustering at various geographic levels and include year fixed effects throughout the analysis.
} 
zoning category. There is a 20 (42) basis point drop in loan interest rates when moving from the least to the average (most) redeployability in an area and zoning category. This result is consistent with Prediction 1b.

Although not reported in Table 2, we find that floating rates are associated with lower interest rates of 63 basis points at the margin $(t$-stat $=-13.18)$ and that a standard deviation increase in leverage increases loan rates by 67 basis points at the margin $(t$-stat $=3.52)$. We find no marginally significant effects on loan rates from the other variables.

Since we include current value as a control, the coefficient on redeployability reflects the effect of zoning flexibility on interest rates that is unrelated to effects embedded in the current value of the property. This likely understates the effect of liquidation value (through zoning) since current price will likely be affected as well by liquidation value.

Column 2 of Table 2 Panel A shows that properties with greater redeployability receive loans significantly more frequently. The dependent variable is the probability of a loan (i.e., whether the property's purchase was financed with a loan, a binary variable). We estimate a linear probability model to avoid making functional form assumptions and so that we may employ fixed effects for the census tract, property type, general zoning category, and year which are generally inconsistent under probit models, for example. We have also run standard logit and probit models without the fixed effects that typically yield similar, and often stronger, results. The coefficient on redeployability is positive and significant, consistent with prediction 1 . However, this result is the only one that does not survive the census tract fixed effects model (discussed below and shown in Panel B), so we are not inclined to place too much weight on this result.

The third column of Table 2 Panel A examines leverage, or the size of the loan as a fraction of the sale price, conditional on a loan being present. All of the control regressors are the same, except, of course, $\log$ (sale price) is removed from this regression since the dependent variable is already scaled by price. Conditional on a loan being granted, redeployability significantly increases the size of loans as well. Going from least to average (maximum) zoning flexibility results in a 6.3

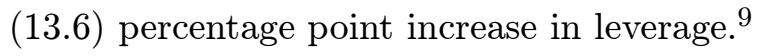

The results in columns 2 and 3 of Panel A provide support for Prediction 1: Assets with greater liquidation values have higher debt levels. The results are particularly supportive of Williamson

\footnotetext{
${ }^{9}$ We report OLS estimates with robust standard errors assuming group-wise clustering at the zip code level. Results are similar using the truncated regression models of Cragg (1971) and Powell (1986) with bootstrapped standard errors.
} 
(1988) since our zoning flexibility variable may be thought of as a measure of redeployability in Williamson's sense.

Column 4 of Panel A details results in support of Prediction 2 that loan maturities significantly increase with liquidation values. A move from the least to the average (most) flexible zoning designation within a neighborhood and zoning category results in approximately 1.7 (3.6) more years of maturity on the loan. Given the mean loan maturity in the sample is roughly 19 years, this is a $8.9(18.9)$ percent increase.

In column 5 of Panel $\mathrm{A}$ we show that loan durations also increase with redeployability. The result is significant at the 10 percent level despite the substantially smaller sample size for this regression. (We require interest rate, duration and amortization data to calculate the duration.) A move from the least to the average (most) redeployable property leads to an increase in duration of approximately $0.3(0.6)$ years. This provides further support for Prediction 2.

Harris and Raviv (1990) claim that when not conditioning on loan size, the promised yield should increase with liquidation value (Prediction 4). This numerical result of their model is not borne out by the data, however, as unconditional interest rates are also decreasing in redeployability in unreported results.

Finally, Prediction 3 states that firms will borrow from one creditor when liquidation value is high and from two creditors when liquidation value is low. To test this prediction, we regress the presence of a second creditor on our redeployability measure. Column 6 of Table 2 Panel A shows that assets with increased redeployability are significantly less likely to be financed by multiple creditors, supporting this prediction. The difference between the least and average (most) redeployable assets translates into a 1.8 (3.9) percentage point decline in the probability of multiple creditors being present. Since the unconditional frequency of multiple creditor presence is only 12 percent (see Table 1), this is a 15 (33) percent decline.

\section{B.2 Census tract fixed effects}

In Table 2 Panel B we repeat the regressions in Panel A of loan characteristics on the redeployability measure using census tract fixed effects. The local economic and social control variables we used in Panel A are no longer appropriate, given our use of very local fixed effects. These tests make use only of variation in zoning designations within a census tract, zoning category, property type, and year. This should alleviate any concerns of unobservable variables affecting our zoning measure and 
financing terms and any plausible endogeneity story. Given the large number of census tracts $(2,075)$ in which our properties fall, a substantial portion of the variation in our redeployability measure is eliminated by the inclusion of tract fixed effects. Nonetheless, the results described in Panel B show that an increase in redeployability results in significantly lower interest rates, higher leverage, longer debt maturity and duration, and less frequent presence of multiple creditors. As mentioned previously, the only result that does not survive census tract fixed effects is debt frequency.

The coefficient estimates are actually slightly higher in the census tract fixed effects specification. Within a census tract, property type, and general zoning category, moving from the least to the average (most) zoning flexibility lowers the interest loan rate by 27 (57) basis points per annum, increases the loan's size relative to the value of the property by 5.9 (12.6) percentage points, lengthens the loan's maturity by 2.8 (6.1) years, increases the loan's duration by $0.17(0.37)$ years, and decreases the probability of borrowing from multiple lenders by 3.6 (7.6) percentage points. These effects are all economically larger than the estimates in Panel A, suggesting that potential endogeneity or omitted variable bias is reducing rather than enhancing our estimates.

Overall, these results provide strong evidence for the importance of redeployability for loan terms. Given two properties of similar type within the same census tract, the property zoned more flexibly typically receives a lower interest rate loan, a greater loan-to-value ratio, longer maturity and longer duration debt and a loan provided by fewer creditors. These findings, and those in Panel A, are strongly supportive of the theoretical predictions detailed in Section I.

\section{B.3 Alternative specifications for current value}

We argue that controlling for current value also controls for property or individual idiosyncracies that may be related to financing and zoning. The results in Table 2 control for current value using the cap rate (current earnings over price) and the log of the sale price as a scale variable. Table 3 provides evidence on the robustness of the results to alternative specifications for current value. In the first and second rows of the table, we include, in addition to the log of the sale price and cap rate, interactions of the cap rate with zoning category and property type dummies. The coefficients on redeployability (both with and without census tract fixed effects) are virtually unchanged and continue to have statistically and economically significant effects on the loan characteristics.

In the third and fourth rows, we add interactions of sale price with zoning category and property types in addition to the cap rate interactions. Our findings are again robust to this specification. 
Finally, in the fifth and sixth rows we add squared and cubed terms of log(sale price) and cap rate to the regression along with all of the interactions above. The point estimates and statistical significance of redeployability are virtually unchanged.

Although not reported, we also confirm that results are robust (and often stronger) to excluding cap rate from the regressions and using just the sale price to control for current value. Since cap rate information is missing from some transactions, we confirm the results on the larger sample not requiring cap rate information. We also confirm that the results are robust to the smallest sample that requires both cap rate and interest rate information across all dependent variables. This ensures that the sample sizes are equal across all five loan characteristics (i.e., the same loan contracts for every loan term).

\section{B.4 Nonlinearities}

Finally, we also check for the presence of non-linearities associated with our redeployability measure. We regress each of our loan characteristics and price on dummy variables for every redeployability value (there are 427 unique values) plus the full set of controls. We then take the estimated dummy coefficients from this regression, representing the effect each redeployability value has on the particular loan terms or price, and regress them on the continuous redeployability measure, its squared term, and cubed term. Note that the errors-in-variables problem is not a concern here since the dependent variable is the estimated coefficient from the first stage and therefore estimation error of this variable will show up in the residual if unrelated to the regressors redeployability, its square, and cube. For all six dependent variables including price, only the first, linear term was significantly different from zero (and positive) at the 5 percent significance level. This indicates that the non-linear terms are rejected in favor of a linear specification for describing the data.

The results provide strong support for the importance of redeployability on the form of the loan contract. We find that redeployable properties receive lower-interest debt, are financed with larger, longer maturity and longer duration loans, and are less frequently financed by multiple creditors. These results provide empirical evidence in favor of the theoretical predictions (in Section I) of Williamson (1988), Shleifer and Vishny (1992), Harris and Raviv (1990), and Hart and Moore (1994). 


\section{Strictness of zoning, law enforcement, and liquidity}

In Table 4 we examine whether the impact of zoning regulations differs across jurisdictions. In particular, one would expect that zoning regulations should matter more in areas with stricter application of zoning rules, stronger overall law enforcement mechanisms, and more liquid markets for redeployed properties. To test this, we repeat the regressions of Table 2 by interacting our redeployability measure with variables designed to capture ease of manipulation of zoning regulations, quality of local law enforcement, and market liquidity. Since these variables are all measured at levels greater than a census tract, regressions using census tract fixed effects are not feasible. However, as shown in Table 2, for many of our results removal of census tract fixed effects yielded weaker findings.

\section{C.1 Zoning strictness}

In Table 4 Panel A we interact the redeployability variable with several measures designed to capture the strictness of local zoning regulation. Our redeployability measure should be more important in jurisdictions with strict zoning rules, and have less impact where adherence is weak.

We capture the strictness of zoning in an area via several measures from multiple data sources. The first two measures come from the Wharton Land Use Control Survey under the Wharton Urban Decentralization Project (see Glaeser and Gyourko (2002)). We first create an index of zoning strictness for an area by taking the average of the percentage of applications for zoning changes that were approved in the local MSA during 1989 (coded as follows $5=0$ to $10 \%, 4=11$ to $29 \%, 3=30$ to $59 \%, 2=60$ to $89 \%, 1=90-100 \%$ ) and the estimated number of months between application for rezoning and issuance of a building permit for the development of a property in the MSA, taking the average for single family units and office buildings (coded as follows $1=$ Less than 3 months, $2=3$ to 6 months, $3=7$ to 12 months, $4=13$ to 24 months, 5=More than 24 months). Appendix B describes in more detail the construction of this variable and its source. Interacting the zoning strictness index with redeployability, Table 4 Panel A shows that property-specific redeployability has a stronger effect on loan characteristics in jurisdictions with strict zoning rules. The interaction coefficients are statistically significant and of the predicted sign (standard errors are clustered at the MSA level here).

The second zoning rigor measure we use is an index of the effectiveness of growth management techniques employed in the MSA through zoning ordinances and permits, also obtained from the 
Wharton Land Use Control Survey. Specifically, survey respondents' assessment of the effectiveness of ordinances, building permits, and zoning ordinances in controlling growth are provided on a scale of 1 (not important) to 5 (very important) and the average across the three categories is the growth management index we employ. Appendix B details the construction of this variable and its source. As Panel A shows, redeployability has a greater effect on all loan characteristics in jurisdictions that use zoning ordinances and permits most effectively to control and manage growth in the area. This indicates that zoning flexibility is a better measure of redeployability in areas where zoning matters more and is adhered to more tightly.

As a third measure of the ease of altering zoning on a property, we employ a property-specific indicator variable for properties with an historic zoning designation. We expect that zoning classifications should be harder to change for historically zoned properties. Consistent with this conjecture, redeployability has an even greater effect on all loan terms other than duration (which has the right sign but is insignificant) for properties zoned historic.

Our final measure for zoning strictness is the fraction of properties in the same zip code that have the same general zoning designation, zoning concentration. It is likely more difficult to change zoning when surrounding properties are zoned similarly. For instance, one of the major criteria in getting a zoning change for a property is consideration for the zoning and use of properties nearby. Thus, zoning redeployability may be a better proxy for liquidation value when it is more difficult to change zoning designations, as measured by the fraction of similarly zoned properties. Table 4 Panel A provides evidence that redeployability has a stronger effect on loan frequency, leverage, debt maturity, loan duration, and the presence of multiple creditors when zoning concentration is high. ${ }^{10}$ Taken together, the four interactions in Panel A demonstrate that redeployability has a substantially stronger effect in areas in which zoning rules are more important and harder to change.

\footnotetext{
${ }^{10}$ Regulation may be more binding when properties of a similar type are clustered in the same region and this in turn seems to have a greater impact on financing terms. This idea may relate to the literature on industrial geographic concentration (e.g., Krugman (1991) and Ellison and Glaeser (1997)), which suggests that concentration can create benefits by facilitating scale economies for industry suppliers and reducing transportation costs (Lall, Koo, and Chakravorty (2003)). It may be interesting to examine these implications for regional growth and financial development, but this is beyond the scope of the present paper.
} 


\section{C.2 Enforcement of law}

Table 4 Panel B examines interactions with variables that proxy for the overall enforcement of law in an area. The first is the number of arresting officers (authorities with arresting powers) per capita in the county in which the property resides, obtained annually from the FBI from 1992 to 1999. This is a broader measure of the county's commitment to legal enforcement. We include state fixed effects in these regressions and cluster standard errors by county. We find significant coefficients on the interaction terms with the predicted sign in all regressions. Loan frequency, leverage, maturity, and duration exhibit a significant positive interaction and interest rate and the presence of multiple creditors regressions exhibit negative interactions between redeployability and arresting officers per capita. These results suggest that the effects of redeployability on all these variables are stronger in counties with relatively stronger law enforcement, as proxied by arresting officers per capita. Although the number of arresting officers is an endogenous variable, it seems to be a reasonable proxy for the area's commitment to law enforcement that is unlikely affected by the zoning assignment of a particular property.

Legal enforcement measures the ability of an administration to monitor the obedience of its subjects. Conversely, corrupted local administrators might modify zoning regulations in favor of special interests. In this case, zoning regulations might be subject to change even when enforcement standards are high. To analyze how corruption might influence zoning, we use the number of federal public corruption convictions per capita for the state in which the property resides. These data are obtained from the Department of Justice from 1992 to 1999. We note that since these are federal convictions they allow for valid cross-state comparisons. In particular, if federal enforcement is equal across states, then we can interpret this variable as capturing more corruption in a state. If, however, federal enforcement varies across states endogenously, then one should be careful interpreting this variable as it could capture both supply and demand effects. We feel that the assumption that federal enforcement is roughly equal across states is a reasonable one. There is an adverse effect of corruption on the effectiveness of zoning. We find negative (though insignificant) coefficients on the interaction terms in the loan frequency and loan maturity and duration regressions, and a positive and significant interaction coefficient in the interest rate regression. Since we only have cross-state variation in the federal corruption conviction variable, these tests have low power. Nonetheless, these results suggest that the effects of redeployability are slightly stronger in less corrupted states. 
Although we interpret the variables with caution, taken together, these results are suggestive of zoning laws being a better proxy for liquidation value in areas where they are more likely to be enforced and perhaps less subject to the influences of corruption.

\section{C.3 Market liquidity}

Panel $\mathrm{C}$ examines interactions with measures of local market liquidity. The first measure we employ is the average of the qualitative ratings by the Wharton Land Use Control Survey respondents comparing the acreage of land zoned versus demanded across single family, multi-family, commercial, and industrial uses, and across various lot sizes (coded on a 1-5 rating scale: 1=Far more than demanded, 5=Far less than demanded). Appendix B details the construction of this measure and its source. When demand for a type of property is high relative to supply, we would expect the redeployment option to be of great use and to be exploited frequently. If, by contrast, land is plentifully available then there should be little incentive to redeploy a property. The results displayed in Panel $\mathrm{C}$ show redeployability has the predicted stronger effect on all loan characteristics (insignificant for duration) when relative demand for land is strong.

The second measure of local market liquidity we employ is the Herfindahl concentration index of property brokers within a 5 mile radius of the property. Liquidation of real assets is very costly in inefficient brokerage markets, and hence we would expect the redeployability option to be less useful in such markets. More broadly, liquid markets should be expected to have more participating brokers, and redeployability should be more cost-effective in these markets. As predicted, we find that redeployability has less of an impact on debt frequency, leverage, debt maturity, and the presence of multiple creditors when broker competition (concentration) is low (high).

Overall, the evidence in Table 4 demonstrates that our redeployability variable has a greater influence on loan terms in precisely those markets where we would predict it to have a stronger effect: areas in which zoning rules are applied consistently and strictly, areas with stronger commitment to law enforcement, and areas where demand for liquidated properties is likely to be strong. This evidence buttresses our earlier results and supports the plausibility of redeployability (through zoning) as a reasonable measure of liquidation value. 


\section{Other measures of liquidation value}

In addition to our zoning measures, we employ other proxies for liquidation value that are more subject to endogeneity concerns but that provide further supporting evidence for the importance of liquidation values on financial contracts.

For robustness, Table 5 reports results from regressing loan contract attributes on other measures of liquidation value. The results detailed in Table 5 Panel A use the full set of controls described in Table 2 Panel A, while Table 5 Panel B reports results from regressions that include census tract fixed effects as described in Table 2 Panel B.

As argued above, liquidation is likely a cheaper and more effective option in competitive brokerage markets. We employ the broker Herfindahl measure as a plausible (inverse) proxy for liquidation value. In the first row of Table 5 Panel $\mathrm{A}$ we show that properties in less competitive brokerage markets receive debt less frequently, receive shorter maturity debt, and are subject to higher interest rates. Since broker Herfindahl is measured over a 5 mile radius, there is little variation in this measure within a census tract, hence the census tract fixed effect specification is not appropriate here.

An historic zoning designation can also substantially reduce a property's redeployability and liquidity. Properties in historic districts often face severe restrictions on changes in appearance and use. In the second row of Table 5 Panel A we analyze the effect of an historic designation on features of loan contracts. We find that properties zoned historic receive significantly fewer and smaller loans, have higher interest rates, and are more likely to be financed by multiple creditors. The economic magnitudes of these effects are large. An historic designation is associated with interest rates that are 33 basis points higher, a 5.2 percentage point reduction in the probability of a loan, a 3.6 percentage point smaller loan-to-value ratio, and a debt maturity that is 3.1 years shorter. The effects on loan duration and presence of multiple creditors are statistically insignificant. As shown in Panel B, the results are generally stronger when controlling for census tract fixed effects. Taken together, these findings suggest that the illiquidity associated with an historic zoning designation can have substantial effects on loan terms.

As a direct (though endogenous) measure of liquidity, we consider the local volume of the market, measured by the number of sales of properties in the same zip code. Though this measure is subject to endogeneity concerns, we show in the third row of Table 5 Panel A that properties in 
areas with high local volume receive debt more frequently, larger loans, and longer maturities and are more likely to be financed by a single creditor. These results are consistent with the hypothesis that liquidation values are higher in high-volume areas.

We next consider zoning concentration, a variable that may also be viewed as a proxy for a property's liquidity. Valuing a commercial real asset requires knowledge of both property and location attributes. If a property is of an unusual type for its neighborhood (for example, an apartment building in a manufacturing district), there are likely to be few potential buyers who have knowledge of both the neighborhood and the property type. The market for this property is likely, therefore, to be thin, resulting in demand illiquidity (Shleifer and Vishny (1992)). ${ }^{11}$ The fourth row of Table 5 Panel A shows that zoning concentration significantly increases loan frequency, leverage, and maturity, and significantly decreases loan interest rates.

To further study the effects of liquidity, we examine the impact of population density in the fifth row of Table 5 Panel A. The population radius variable is the minimum of three miles and the radius surrounding the property which encompasses 100,000 people. This variable is negatively correlated with density and is proposed as a measure of illiquidity. We find that properties in less dense areas receive significantly fewer and smaller loans, and the presence of multiple creditors is more likely. More and less dense areas vary in many respects other than the liquidity of their property markets, but the results nonetheless suggest that liquidation values impact loan contract attributes in the predicted way. Census tract fixed effects are inappropriate for the local volume, zoning concentration, and population density regressions because these variables exhibit little or no within-tract variation.

The final row in Table 5 Panel A considers the financing of older (age of 30 years or more) properties. Older properties are less durable and should have lower liquidation values. It is a direct prediction of Hart and Moore (1994) that less durable assets should receive less debt financing and that the debt they receive should be of shorter maturity. We find that older properties receive debt significantly less frequently and are financed with shorter maturity and shorter duration debt. Older properties are also much more likely to be financed by multiple creditors. Given the presence of debt, a property older than 30 years is more than twice as likely to be financed by multiple creditors than a typical property. These results are confirmed in the fixed effects regressions shown

\footnotetext{
${ }^{11}$ The local nature of commercial real estate markets is established in Garmaise and Moskowitz (2004a) and further explored in Garmaise and Moskowitz (2003, 2004b).
} 
in Panel B.

Taken together, these results provide further supporting evidence in favor of the theoretical predictions linking liquidation values to loan contract features, though we acknowledge these variables are more open to endogeneity concerns.

\section{Liquidation value, asset prices, and broker activity}

Finally, although the primary focus of our analysis is on the features of the debt contract, we analyze additional implications of the theories and additional tests on the usefulness of our redeployability measure by examining the relation between redeployability and prices and broker activity. Recognizing these regressions, particularly for prices, are more open to endogeneity concerns, we interpret the following results with caution. Nevertheless, the results are generally supportive of our interpretation of zoning flexibility as a measure of liquidation value.

Table 6 provides a test of Prediction 5 that an asset's market value is increasing in its liquidation value. In Panel A, we regress the log of the property sale price on our redeployability measure and report the result in the first column of the table. The regressors include current earnings as a measure of property size and profitability and the usual set of controls from Table 2 Panel A, excluding log of price, of course. The regression yields a significant positive coefficient, indicating that higher liquidation value is associated with higher market value, though as we noted earlier the direction of causality in this price regression is not indisputable. Moving from the lowest to the average (highest) level of redeployability in an area increases the market price by 1.5 (3) percent. The results from the census tract fixed effects regression, described in Panel B, are very similar. In the second column of Panels $\mathrm{A}$ and $\mathrm{B}$, we regress the log of the residual sale price, in excess of the log of earnings (essentially forcing the coefficient on earnings to be one), and obtain similar results, though with a slightly larger coefficient. Interestingly, the results in the first two columns of both panels contrast with the general finding in the residential real estate market that tighter zoning is associated with higher prices (Quigley and Rosenthal (2004)). This discrepancy may arise largely from between versus within neighborhood comparisons. Our result that zoning flexibility increases property values is property-specific, relative to properties within a neighborhood and census tract. The Quigley and Rosenthal (2004) results are between neighborhoods. It may well be that zoning flexibility is valuable for each property owner, but that the negative externalities 
of zoning flexibility reduce property values at the neighborhood level. Also, as noted earlier, endogeneity of zoning between neighborhoods is likely a concern (Glaeser and Gyourko (2002)), but less so within neighborhoods.

We have presented evidence that assets with high liquidation values receive financing more frequently, and at better terms, and trade at higher prices. Another benefit of such assets is that they should be easier to market and less subject to fire sales (Shleifer and Vishny (1992), Pulvino (1998), and Stromberg (2000)). To test this hypothesis we consider the effect of redeployability on the probability that the seller of an asset hires a professional broker. Brokers reduce the time to sale (Knoll (1988), Yang and Yavas (1995) and Williams (1998)) and assist in the provision of bank finance to expedite the deal (Garmaise and Moskowitz (2003)). Both of these functions are presumably less important for assets with high liquidation value. In addition, Garmaise and Moskowitz (2003) find evidence that more liquidity-constrained sellers are more likely to hire a broker. To test these implications we regress whether or not the seller hired a broker on our redeployability measure of liquidation value and the full set of controls. We include as an additional control the Herfindahl measure of broker concentration in the 5 mile radius surrounding the property. Different markets may have differing levels of broker participation for a variety of reasons. We are interested in studying the marginal effect of liquidation value on the likelihood of broker usage, given the ambient level of broker competition. Column 3 of Table 6 Panel A presents the result from the broker presence regression. Redeployability has a significantly negative coefficient. Panel B shows that this result holds in the presence of census tract fixed effects as well. Properties with high liquidation values are more often marketed without the assistance of a broker, either because they may be purchased by a wider set of potential buyers or because buyers of these assets do not require the aid of a broker in procuring financing.

\section{Conclusion}

Despite the breadth of theory on incomplete contracting for financial structure, supporting evidence is sparse. This is in part due to the difficulty in obtaining ex ante measures of asset liquidation value and observing asset-specific contracts. We provide novel evidence linking asset liquidation value, measured through regulation of zoning flexibility, and debt structure using a unique sample of asset-specific commercial loan contracts. Greater asset redeployability and higher liquidation values 
significantly alter the terms of loan contracts in a manner consistent with theories of incomplete contracting and transaction costs. More redeployable assets are financed at lower interest rates, receive larger, longer maturity, and longer duration loans, and are less likely to face multiple creditors. Extending these results to non-debt contracts and loans without the non-recourse feature may shed more light on the importance of contractual incompleteness and transaction costs in determining the boundaries of the firm.

In addition to incomplete contracting theories of capital structure, our results also emphasize the importance of collateral in financial contracting and credit market rationing. While most of the literature analyzes collateral requirements rather than collateral quality (e.g., Stiglitz and Weiss (1981) and Wette (1983)), the effect of collateral quality on credit rationing is a potentially important question that has not received detailed empirical study. For instance, we show that higher liquidation values and interest rates are negatively correlated (predicted by Bester (1985)), yet we also find that higher liquidation values imply larger loans. Thus, better collateral decreases the amount of credit rationing as well as the cost of borrowing.

There is also a growing literature that analyzes the interaction between bank monitoring, loan terms, borrower's financial structure, and liquidation value. ${ }^{12}$ Although we cannot identify bank monitoring or related lending in the data, it may be possible to use our empirical identification of redeployability (zoning flexibility) to test these models when measures of monitoring and related lending are available. In particular, zoning designations themselves my represent hard information but the strictness of zoning in an area may represent "soft" information only available to local lenders. It would be interesting to examine the types of banks that use these two pieces of information. Analyzing the role of collateral in the tradeoff between credit rationing and pricing, as well as the interplay with monitoring and relationship lending, may be an interesting avenue for future research.

\footnotetext{
${ }^{12}$ See Gorton and Winton (2002) for a comprehensive survey.
} 


\section{References}

Baker, George P., and Thomas N. Hubbard H., "Contractibility and Asset Ownership: On-Board Computers and Governance in U.S. Trucking," NBER working paper no. 7634 (2000).

Baker, George P., and Thomas N. Hubbard H., "Make versus buy in Trucking: Asset Ownership, Job Design, and Information," American Economic Review 94 (2003), 551-572.

Benmelech, Efraim, "Asset Salability and Debt Maturity: Evidence from 19th Century American Railroads," Working paper, Graduate School of Business, University of Chicago (2003).

Bester, Helmut, "Screening vs. Rationing in Credit Markets with Imperfect Information," American Economic Review 75 (1985), 850-855.

Bolton, Patrick, and David Scharfstein "Optimal Debt Structure with Multiple Creditors," Journal of Political Economy 104 (1996), 1-26.

Braun, Matias, "Financial Contractibility and Assets' Hardness: Industrial composition and Growth," Working paper, Harvard University (2002).

Detragiache, Enrica, Paolo Garella, and Luigi Guiso, "Multiple versus single banking relationships: Theory and evidence," Journal of Finance 55 (2000), 1133-1161.

Diamond, Douglas, "Debt Maturity Structure and Liquidity Risk," Quarterly Journal of Economics, 106 (1991), 709-737.

Diamond, Douglas, "Committing to Commit," AFA Presidential Address (2004), forthcoming Journal of Finance.

Ellison, Glenn, and Edward Glaesar, "Geographic concentration in U.S. manufacturing: a dartboard approach," Journal of Political Economy 105 (1997), 889-927.

Esty, Benjamin C., and William L. Meginson "Creditor rights, enforcement, and debt ownership structure: Evidence from the global syndicated loan market," Journal of Financial and Quantitative Analysis 38 (2003), 37-59.

Garmaise, Mark J., and Tobias J. Moskowitz, "Informal Financial Networks: Theory and Evidence," Review of Financial Studies, (2003), Vol. 16 No. 4, 1007-1040.

Garmaise, M., and T. Moskowitz, "Confronting Information Asymmetries: Evidence from Real Estate Markets," Review of Financial Studies, (2004a), Vol. 17 No. 2, 405-437.

Garmaise, M., and T. Moskowitz, "More Banks, Less Crime? The Real and Social Effects of Bank Competition," CRSP working paper, (2004b).

Gilson, Stuart C., "Transaction Costs and Capital Structure Choice: Evidence from Financially Distressed Firms," Journal of Finance 52 (1997), 161-196.

Glaeser, Edward, and Joseph Gyourko, "The Impact of Building Restrictions on Housing Affordability," Working Paper, Wharton (2002).

Gorton, Gary, and Andrew Winton, "Financial Intermediation," NBER working paper no. 8928 (2002).

Grossman, Sanford, and Oliver Hart, "The Costs and the Benefits of Ownership: A Theory of Vertical and Lateral Integration," Journal of Political Economy 94 (1986), 691-719.

Harris, Milton and Artur Raviv, "Capital Structure and the Informational Role of Debt," Journal of Finance 45 (1990), 321-49. 
Harris, Milton and Artur Raviv, "The Theory of capital Structure," Journal of Finance 46 (1991), 297-355.

Hart, Oliver and John Moore, "Property Rights and the Nature of the Firm," Journal of Political Economy 98 (1990), 1119-58.

Hart, Oliver, "Firms, Contracts and Financial Structure," Clarendon Press, Oxford, 1995.

Hart, Oliver and John Moore, "A Theory of Debt Based on the Inalienability of Human capital," Quarterly Journal of Economics 109 (1994), 841-79.

Kaplan, Steven N., and Per Stromberg, "Financial Contracting Theory Meets the Real World: An Empirical Analysis of Venture Capital Contracts," Review of Economic Studies 70 (2003), 281-315.

Knoll, M., 1988, "Uncertainty, Efficiency, and the Brokerage Industry," Journal-of-Law-and-Economics, 31, 249-263.

Krugman, Paul, "Increasing returns and economic geography," Journal of Political Economy 99 (1991), 483-499.

Lall, Somik, Jun Koo, and Sanjoy Chakravorty, "Diversity Matters: The Economic Geography of Industry Location in India," World Bank Policy Research Working Paper 3072, June 2003.

McMillen, Daniel P., and John F. McDonald, "A Simultaneous Equations Model of Zoning and Land Values, " Regional Science and Urban Economics 21 (1991), 55-72.

McMillen , Daniel P., and John F. McDonald, "Land Values in a Newly Zoned City," The Review of Economics and Statistics, 84 (2002), 62-72.

Ongena, Steven, and David C. Smith "What determines the number of bank relationships? Crosscountry evidence," Journal of Financial Intermediation 9 (2000), 26-56.

Pogodzinski, J.M., and Tim Sass, "Measuring the Effects of Municipal Zoning Regulations: A Survey," Urban Studies 28 (1991), 597-621.

Pollakowski, H., and Susan Wachter, "The Effect of Land Use Constraints on Housing Prices," Land Economics 66 (1990), 315-324.

Pulvino, Todd C., "Do Fire-Sales Exist?" An Empirical Investigation of Commercial Aircraft Transactions," Journal of Finance 53 (1998), 939-78.

Pulvino, Todd C., "Effects of Bankruptrcy Court Protection on Asset Sales," Journal of Financial Economics 52 (1998), 151-86.

Quigley, John M., and Larry A. Rosenthal, "The Effects of Land-Use Regulation on the Price of Housing: What Do We Know? What Can We Learn?," Working Paper, University of California, Berkeley, (2004).

Rajan, Raghuram G., and Luigi Zingales, "What Do We Know about capital Structure? Some Evidence from International Data," Journal of Finance 50 (1995), 1421-60.

Shleifer, Andrei, and Robert W. Vishny, "Liquidation Values and Debt Capacity: A Market Equilibrium Approach" Journal of Finance 47(1992), 143-66.

Stein, J., 1997, "Nonrecourse Carveouts: How Far is Far Enough," Real Estate Review, 27, 3-11.

Stiglitz, Joseph, and Andrew Weiss, "Credit Rationing in Markets with Imperfect Information," American Economic Review 71 (1981), 393-410.

Stromberg, Per, "Conflicts of Interests and Market Illiquidity in Bankruptcy Auctions: Theory and Tests," Journal of Finance 55 (2000), 2641-92. 
Titman, Sheridan, Stathis Tompaidis, and Sergey Tsyplakov, "Determinants of Credit Spreads in Commercial Mortgages," Working Paper, University of Texas at Austin, (2004).

Wallace, Nancy, "The market effects of zoning undeveloped land: Does zoning follow the market?," Journal of Urban Economics 23 (1988), 307-326.

Wette, Hildegard C., "Collateral in Credit Rationing in Markets with Imperfect Information: Note," American Economic Review 73 (1983), 442-45.

Williams, J., 1998, "Agency and Brokerage of Real Assets in Competitive Equilibrium," Review of Financial Studies, 11, 239-280.

Williamson, Oliver E., "Markets and Hierarchies: Analysis and Antitrust Implications," New York Free Press (1975).

Williamson, Oliver E., "Corporate finance and Corporate Governance," Journal of Finance 43 (1988), 567-91.

Wooldridge, Jefferey M., "Econometric Analysis of Cross Section and Panel Data," MIT Press, Cambridge, $M A$ (2002).

Yang, S., and A. Yavas, 1995, "Bigger Is Not Better: Brokerage and Time on the Market", Journal of Real Estate Research, 10, 23-33. 


\section{Appendix A: An example of the zoning code from NYC zoning of residential districts}

Table AI presents a detailed description of each of the residential zoning districts in New York City as an example of the variation in zoning laws employed to capture liquidation values across real assets. A summary of the zoning code and the associated permitted uses of the property as defined by the code are reported for residential districts in NYC only. Similar measures are applied for the districts within the other 8 broad zoning categories: organizations, waterfront, manufacturing, business, commercial, commercial/manufacturing, historic, and residential and across all other zoning districts and cities in our sample from 1992 to 1999 covering 12 states and roughly 850 different zip codes.

Table A1:

An Example of the Zoning Code: NYC Zoning of Residential Districts

\begin{tabular}{|c|c|c|c|c|c|c|c|c|}
\hline \multirow{3}{*}{$\begin{array}{l}\text { Zoning } \\
\text { Designation }\end{array}$} & \multirow[b]{3}{*}{ Uses } & \multirow{3}{*}{$\begin{array}{l}\text { Maximum floor } \\
\text { area ratio }\end{array}$} & \multirow{3}{*}{$\begin{array}{l}\text { Minimum required } \\
\text { open space ratio }\end{array}$} & \multirow{3}{*}{$\begin{array}{l}\text { Maximum lot } \\
\text { coverage }\end{array}$} & \multicolumn{2}{|c|}{$\begin{array}{l}\text { Minimum required lot } \\
\text { area (sq. ft.) }\end{array}$} & \multirow{2}{*}{\multicolumn{2}{|c|}{$\begin{array}{c}\text { Maximum number of } \\
\text { dwelling units or rooms } \\
\text { per acre }\end{array}$}} \\
\hline & & & & & per dwelling & per zoning & & \\
\hline & & & & & unit & room & units & rooms \\
\hline R1-1 & Single-family detached residence & 0.50 & 150 & - & 9500 & - & 4 & - \\
\hline $\mathrm{R} 1-2$ & Single-family detached residence & 0.50 & 150 & - & 5700 & - & 7 & - \\
\hline $\mathrm{R} 2$ & Single-family detached residence & 0.50 & 150 & - & 3800 & - & 11 & - \\
\hline $\mathrm{R} 2 \mathrm{X}$ & Single-family detached residence & 0.50 & 150 & - & 3800 & - & 11 & - \\
\hline \multirow[t]{2}{*}{ R3-1 } & Single, two-family detached, & & & & & & & \\
\hline & semi-detached residence & 0.50 & - & 35 & $1040 / 1450$ & - & $30 / 42$ & - \\
\hline \multirow{2}{*}{$\begin{array}{l}\text { R3-2 } \\
\text { R3A }\end{array}$} & General residence & 0.50 & - & 35 & $1040 / 1450$ & - & $30 / 42$ & - \\
\hline & $\begin{array}{l}\text { Single, two-family detached, } \\
\text { zero lot line residence }\end{array}$ & 0.50 & - & 35 & $1040 / 1450$ & - & $30 / 42$ & - \\
\hline $\mathrm{R} 4$ & General residence & 0.75 & - & 45 & 970 & - & 45 & - \\
\hline R4-1 & $\begin{array}{l}\text { Single, two-family detached, } \\
\text { semi-detached, zero line residence }\end{array}$ & 0.75 & - & 45 & $686-970$ & - & $45 / 65$ & - \\
\hline $\mathrm{R} 4 \mathrm{~A}$ & Single, two-family detached residence & 0.75 & - & 45 & $686 / 970$ & - & $45 / 65$ & - \\
\hline $\mathrm{R} 4 \mathrm{~B}$ & $\begin{array}{l}\text { Single, two-family detached } \\
\text { residences of all types }\end{array}$ & 0.75 & - & 45 & $686 / 970$ & - & $45 / 65$ & - \\
\hline $\mathrm{R} 5$ & General residence & 1.25 & - & 55 & 605 & - & 72 & - \\
\hline R5B & General residence & 1.65 & & 55 & $545 / 605$ & - & 80 & - \\
\hline $\mathrm{R} 6$ & General residence & $0.78-2.43$ & 27.5 to 39.5 & - & - & 109 to 99 & $160 / 176$ & $400 / 460$ \\
\hline $\mathrm{R} 7$ & General residence & $0.87-3.44$ & 15.5 to 22.0 & - & - & 84 to 77 & $207 / 226$ & $519 / 566$ \\
\hline $\mathrm{R} 8$ & General residence & $0.94-6.02$ & 5.9 to 10.7 & - & - & 59 to 45 & $295 / 387$ & $738 / 968$ \\
\hline $\mathrm{R} 9$ & General residence & $0.99-7.52$ & 1.0 to 6.2 & - & - & 45 to 41 & $387 / 425$ & $968 / 1062$ \\
\hline $\mathrm{R} 10$ & General residence & 10 & None & - & - & 30 & 581 & 1452 \\
\hline
\end{tabular}

Source: NYC Zoning Handbook

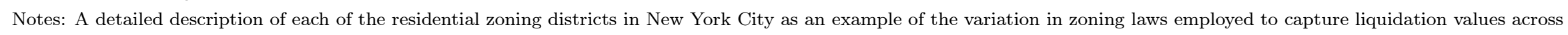
real assets. A summary of the zoning code and the associated permitted uses of the property as defined by the code are reported for residential districts in NYC only. Similar measures

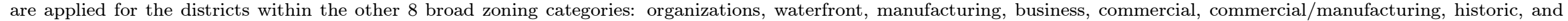
residential and across all other zoning districts and cities in our sample. 


\section{Appendix B: Variable description and construction}

For reference, a list of the construction of the variables used in the paper and their sources:

Redeployability (flexibility of use): the scaled within zoning category and jurisdiction numeric value associated with a given property's zoning ordinance. For property $p$ with zoning ordinance $A$ - $n$ in jurisdiction $j$, this is $\frac{n}{\max \left(n \in P_{(A, j)}\right)}$, where $P_{(A, j)}$ is the set of properties within jurisdiction $j$ that have the same general zoning category $A$. Redeployability is the numeric value indicating flexibility of use $n$ relative to the maximum flexibility within a given property type $A$ and local jurisdiction $j$ which sets the zoning code. (source: Comps)

Zoning category: dummy variables for the broad zoning designation of a property. For property $p$ with zoning ordinance $A$. $n$, this is $A$. There are eight broad zoning categories in the sample: organizations, waterfront, manufacturing, residential, business, commercial, commercial-manufacturing, and historic. (source: Comps)

Zoning concentration (within zip code): for property $p$ with zoning ordinance $A$.n this is the fraction of properties in the same zip code as property $p$ that have the same broad zoning category designation $A$. (source: Comps)

Debt frequency: a binary variable for whether the property was financed with bank debt (occuring 71 percent of the time). (source: Comps)

Leverage: the ratio of total value of bank debt borrowed on the property to the sale price. (source: Comps)

Debt maturity: the maturity of the bank loan contract in years. (source: Comps)

Loan interest rate: the annual percentage interest rate on the bank loan contract and whether it is floating or fixed. (source: Comps)

Multiple creditors: a binary variable for the presence of more than one creditor making a loan on the property. Commercial properties have first and second trust deeds (mortgages), where the latter has lower priority claim on the real asset. These occur about 12 percent of the time and indicate the presence of more than one creditor. (source: Comps)

Capitalization rate: the current or most recent annual earnings on the property divided by the sale price. (source: Comps)

Property type: dummy variables indicating 10 mutually exclusive types: retail, commercial, industrial, apartment, mobile home park, special, residential land, industrial land, office, and hotel. (source: Comps)

Bank Herfindahl: the Herfindahl concentration index of bank loans being made to properties within a 15 mile radius of a given property. (source: Comps)

Broker activity: a dummy variable for whether a broker is involved in the deal, acting as an agent of either the buyer or seller (occuring 65 percent of the time). (source: Comps) 
Broker Herfindahl: the Herfindahl concentration index of brokerage activity (acting as agents only) within a 15 mile radius of a given property. (source: Comps)

Local volume (within zip code): the number of properties sold within the same zip code as the property. (source: Comps)

Price variation: the cross-sectional standard deviation of capitalization rates on properties within a five mile radius of a given property. (source: Comps)

Crime risk: A crime score index comprising the seven part one offenses of the FBI: homicide, rape, aggravated assault, robbery, burglary, larceny, and motor vehicle theft. The crime risk scores measure the probability that a certain crime will be committed in a given location relative to the county level of crime. Hence, this is a relative (within county) crime risk measure. Crime scores are provided at three points in time: 1990, 1995, and 2000. Each property is matched with the crime score index for its latitude and longitude coordinates, obtaining a property specific crime score. Both the level of crime risk (relative to the county level) and the growth in crime risk (change in relative crime risk from 1990 to 1995) are employed as control variables. (source: CAP Index, Inc.)

Population radius: a measure of population density, which is the minimum of three miles or the number of miles surrounding a property (latitude and longitude coordinates) needed to encompass 100,000 people. (source: CAP Index, Inc.)

Population: the 1990 population (number of inhabitants) and the growth rate in population from 1990 to 2000 for the census tract within which each property resides. (source: U.S. Census Bureau 1990 and 2000).

Per capita income: the 1990 per capita income (total income divided by population) and the growth rate in per capita income from 1990 to 2000 for the census tract within which each property resides. (source: U.S. Census Bureau 1990 and 2000).

Median home value: the 1990 median value of a home (in 1990 \$U.S.) and the growth rate in median home value from 1990 to 2000 for the census tract within which each property resides. (source: U.S. Census Bureau 1990 and 2000).

Zoning strictness index: the average of the following two measures from the Wharton Land Use Control Survey (WLUCS), Wharton Urban Decentralization Project: the percentage of applications for zoning changes that were approved in the local MSA during 1989, and the estimated number of months between application for rezoning and issuance of a building permit for the development of a property in the MSA. The first variable is ZONAPPR from the WLUCS - the estimated percentage of applications for zoning changes approved during the past twelve month period in the MSA coded from $1-5$ as follows: $[1=0$ to $10 \%, 2=11$ to $29 \%, 3=30$ to $59 \%, 4=60$ to $89 \%, 5=90-100 \%$ ]. The second variable is the average of the following three variables: 
1. PERMLT50 - the estimated number of months between application for rezoning and issuance of building permit for the development of a subdivision of less than 50 single family units coded as follows: [ $1=$ Less than 3 months, $2=3$ to 6 months, $3=7$ to 12 months, $4=13$ to 24 months, $5=$ More than 24 months, $6=\mathrm{N} / \mathrm{A}$ ].

2. PERMGT50 - the estimated number of months between application for rezoning and issuance of building permit for the development of a subdivision of more than 50 single family units coded as follows: [ $1=$ Less than 3 months, $2=3$ to 6 months, $3=7$ to 12 months, $4=13$ to 24 months, $5=$ More than 24 months, $6=\mathrm{N} / \mathrm{A}$ ].

3. PERMOFF - the estimated number of months between application for rezoning and issuance of building permit for the development of an office building of under 100,000 square feet coded as follows: [ $1=$ Less than 3 months, $2=3$ to 6 months, $3=7$ to 12 months, $4=13$ to 24 months, $5=$ More than 24 months, $6=\mathrm{N} / \mathrm{A}]$.

The zoning strictness index is computed as $(5-Z O N A P P R)+(P E R M L T 50+P E R M G T 50+$ $P E R M O F F$ )/3), excluding MSA's with 6=N/A. (source: Wharton Land Use Control Survey, Wharton Urban Decentralization Project, Development Regulation Survey Questionnaire, 1989. Also see Glaeser and Gyourko (2002)).

Growth management index: the effectiveness of growth management techniques through ordinances, zoning ordinances, and permits employed in the MSA obtained from the Wharton Land Use Control Survey. The average of the variables GROMAN2, GROMAN3, and GROMAN8 are employed as the growth management index. GROMAN2, 3, and 8 are quantitative ratings by survey respondents of the effectiveness of growth management techniques in controlling growth in their community using ordinances, building permits, and zoning ordinances, respectively. The rating is on a scale of $1-5$ and is coded as follows: $[1=$ Not important, $5=$ Very important]. (source: Wharton Land Use Control Survey, Wharton Urban Decentralization Project, Development Regulation Survey Questionnaire, 1989. Also see Glaeser and Gyourko (2002)).

Demand-to-supply: the average of the quantitative ratings of survey respondents from the Wharton Land Use Control Survey on the ratio of demand for land uses relative to the acreage of land zoned for those uses across single family, multi-family, commercial, and industrial uses, and across various lot sizes. Specifically, the measure of demand to supply is the average of the following variables:

1. DLANDUS1-4 - quantitative rating by survey respondent comparing the acreage of land zoned versus demand for the following land uses: Single family, Multi-family, Commercial, and Industrial. [1-5 rating scale: $1=$ Far more than demanded, $5=$ Far less than demanded, $0=$ No opinion or No reply].

2. DLOTSIZ1-5 - quantitative rating by survey respondent comparing the availability of land zoned versus demand for the following single family residential lot sizes: Less than 4,000 square feet, 4,000 to 8,000 sq. ft., 8,000-10,000 sq. ft., 10,000-20,000 sq. ft., and More than 20,000 sq. ft. [1-5 rating scale: $1=$ Far more than demanded, $5=$ Far less than demanded, $0=$ No opinion or No reply]. 
excluding zeros or no replies. (source: Wharton Land Use Control Survey, Wharton Urban Decentralization Project, Development Regulation Survey Questionnaire, 1989. Also see Glaeser and Gyourko (2002)).

\#Arresting officers per capita: yearly number of arresting officers (authorities with arresting powers) per capita in the county in which the property resides from 1992 to 1999. (source: FBI)

\#Federal corruption convictions per capita: yearly number of federal public corruption convictions per capita for the state in which the property resides from 1992 to 1999. (source: Department of Justice) 
Table 1:

\section{Summary Statistics of Zoning Designations, Commercial Real Estate Transactions, and Property Types}

\begin{tabular}{|c|c|c|c|c|c|c|c|c|}
\hline \multirow[b]{2}{*}{ Zoning category } & \multicolumn{7}{|c|}{ Panel A: Characteristics of properties across general zoning category } & \multirow[b]{2}{*}{$\begin{array}{r}\text { Zoning } \\
\text { codes }\end{array}$} \\
\hline & Number & $\begin{array}{r}\text { Debt } \\
\text { frequency }\end{array}$ & Leverage & Price & $\begin{array}{r}\text { Maturity } \\
\text { (Duration) }\end{array}$ & $\begin{array}{r}\text { Loan } \\
\text { rate }\end{array}$ & $\begin{array}{l}\text { Multiple } \\
\text { creditors }\end{array}$ & \\
\hline All properties & 14,159 & 0.71 & 0.71 & $2,386,767$ & $15(6.8)$ & 8.28 & 0.12 & 161 \\
\hline Organizations $(\mathrm{O})$ & 311 & 0.63 & 0.72 & $3,495,907$ & $10(7.9)$ & 8.25 & 0.10 & 5 \\
\hline Waterfront (W) & 6 & 0.67 & 0.85 & $4,887,500$ & $15(8.6)$ & 7.00 & 0.25 & 3 \\
\hline Manufacturing (M) & 3,188 & 0.68 & 0.72 & $1,807,378$ & $10(6.8)$ & 8.73 & 0.13 & 25 \\
\hline Residential (R) & 7,917 & 0.81 & 0.74 & $1,404,530$ & $25(10.0)$ & 7.84 & 0.13 & 36 \\
\hline Business (B) & 1,827 & 0.67 & 0.72 & $3,478,963$ & $7(6.4)$ & 8.65 & 0.07 & 21 \\
\hline Commercial (C) & 4,878 & 0.68 & 0.67 & $3,138,222$ & $10(6.9)$ & 8.64 & 0.12 & 53 \\
\hline Comm./Manu. (CM) & 252 & 0.74 & 0.74 & $1,003,192$ & $10(6.6)$ & 8.74 & 0.19 & 4 \\
\hline Historic $(\mathrm{H})$ & 258 & 0.68 & 0.66 & $3,581,531$ & $10(7.9)$ & 9.08 & 0.13 & 4 \\
\hline \multicolumn{9}{|c|}{ Panel B: Distribution of zoning category across property type } \\
\hline Property type & $\mathrm{O}$ & $\mathrm{W}$ & M & $\mathrm{R}$ & $\mathrm{B}$ & $\mathrm{C}$ & $\mathrm{CM}$ & $\mathrm{H}$ \\
\hline Retail & 94 & 2 & 227 & 247 & 837 & 1,898 & 87 & 45 \\
\hline Commercial & 35 & 0 & 107 & 127 & 218 & 749 & 31 & 68 \\
\hline Industrial & 20 & 0 & 1,953 & 44 & 78 & 230 & 68 & 25 \\
\hline Apartment & 28 & 0 & 253 & 5,860 & 110 & 383 & 12 & 65 \\
\hline Mobile home park & 1 & 0 & 1 & 19 & 0 & 2 & 0 & 1 \\
\hline Special & 10 & 0 & 5 & 176 & 18 & 47 & 3 & 2 \\
\hline Residential land & 38 & 0 & 37 & 1,160 & 14 & 57 & 1 & 6 \\
\hline Industrial land & 5 & 0 & 362 & 16 & 3 & 16 & 4 & 2 \\
\hline Office & 74 & 4 & 227 & 233 & 520 & 1,396 & 38 & 27 \\
\hline Hotel & 6 & 0 & 16 & 35 & 29 & 100 & 8 & 17 \\
\hline \multicolumn{9}{|c|}{ Panel C: Characteristics of properties across property type } \\
\hline Property type & Number & $\begin{array}{r}\text { Debt } \\
\text { frequency }\end{array}$ & Leverage & Price & $\begin{array}{r}\text { Maturity } \\
\text { (Duration) }\end{array}$ & $\begin{array}{l}\text { Loan } \\
\text { rate }\end{array}$ & $\begin{array}{l}\text { Multiple } \\
\text { creditors }\end{array}$ & $\begin{array}{l}\text { Cap } \\
\text { rate }\end{array}$ \\
\hline Retail & 3,949 & 0.74 & 0.72 & $1,610,357$ & $10(6.6)$ & 8.80 & 0.10 & 10.33 \\
\hline Commercial & 1,650 & 0.40 & 0.68 & $1,670,517$ & $4(4.9)$ & 8.97 & 0.07 & 10.38 \\
\hline Industrial & 3,784 & 0.70 & 0.73 & $1,589,490$ & $10(6.7)$ & 8.72 & 0.12 & 9.97 \\
\hline Apartment & 6,997 & 0.90 & 0.74 & $1,529,293$ & $25(10.0)$ & 7.77 & 0.13 & 10.04 \\
\hline Mobile home park & 41 & 0.76 & 0.71 & $5,087,748$ & $10(6.8)$ & 8.46 & 0.19 & 9.19 \\
\hline Special & 290 & 0.70 & 0.77 & $2,109,284$ & $10(6.2)$ & 8.88 & 0.20 & 11.00 \\
\hline Residential land & 1,713 & 0.41 & 0.75 & $1,004,216$ & $7(4.1)$ & 8.91 & 0.11 & $\mathrm{~N} / \mathrm{A}$ \\
\hline Industrial land & 568 & 0.37 & 0.74 & 921,757 & $8(4.8)$ & 9.06 & 0.08 & $\mathrm{~N} / \mathrm{A}$ \\
\hline Office & 3,380 & 0.67 & 0.68 & $6,595,045$ & $10(6.6)$ & 8.60 & 0.10 & 10.17 \\
\hline Hotel & 270 & 0.63 & 0.69 & $10,574,474$ & $14(6.6)$ & 8.82 & 0.22 & 12.21 \\
\hline
\end{tabular}

Notes: Characteristics of properties in the COMPS database covering the period January 1, 1992 to March 30, 1999 are reported. Panel A reports the average loan frequency, loan-to-value (LTV) ratio, sale price, median loan maturity and duration (in parentheses) in years, loan rate (\% per year), frequency of multiple lenders (second/subordinated loans), property age, and number of unique zoning code ordinances for all properties and for each general zoning category. Panel B reports the distribution of general zoning categories across 10 property types. The number of properties under each of the eight broad zoning categories for each property type are reported. Panel C reports the average loan frequency, loan-to-value (LTV) ratio, sale price, loan maturity (in years), loan rate (percent per year), frequency of multiple lenders (second/subordinated loans), and capitalization rate (net income on the property in the previous year divided by the sale price, in percent) across the property types. 
Table 2:

Asset Redeployability (Measured by Zoning Intensity of Use) and Debt Contracts

\begin{tabular}{|c|c|c|c|c|c|c|}
\hline \multicolumn{7}{|c|}{ Panel A: Local economic and social controls } \\
\hline Dependent variable $=$ & $\begin{array}{c}\text { Interest } \\
\text { rate }^{\dagger}\end{array}$ & $\begin{array}{c}\text { Debt } \\
\text { frequency }\end{array}$ & Leverage & $\begin{array}{c}\text { Debt } \\
\text { maturity }\end{array}$ & $\begin{array}{c}\text { Loan } \\
\text { duration }\end{array}$ & $\begin{array}{l}\text { Multiple } \\
\text { creditors }\end{array}$ \\
\hline \multirow{4}{*}{$\begin{array}{l}\text { Redeployability } \\
\text { zoning intensity of use } \\
\log (\text { size })\end{array}$} & -0.4569 & 0.1195 & 0.1475 & 3.8760 & 0.7048 & -0.0428 \\
\hline & $(-2.25)$ & $(2.44)$ & $(3.03)$ & $(2.39)$ & $(1.87)$ & $(-2.00)$ \\
\hline & -0.1381 & -0.0180 & & -0.9427 & 0.0391 & -0.0138 \\
\hline & $(-5.15)$ & $(-2.85)$ & & $(-4.40)$ & $(0.85)$ & $(-6.59)$ \\
\hline \multirow[t]{2}{*}{ Cap rate (current value) } & 0.0162 & 0.0087 & 0.0058 & 0.1488 & -0.0176 & -0.0029 \\
\hline & $(3.17)$ & $(7.87)$ & $(6.06)$ & $(4.10)$ & $(-2.03)$ & $(-7.23)$ \\
\hline \multirow{2}{*}{$\log ($ age $)$} & 0.0105 & -0.0165 & -0.0208 & -0.2344 & 0.0473 & 0.0166 \\
\hline & $(0.48)$ & $(-3.12)$ & $(-4.76)$ & $(-1.51)$ & $(1.21)$ & $(8.13)$ \\
\hline \multirow[t]{2}{*}{ Bank Herfindahl } & -2.2856 & 0.8032 & 0.5307 & -5.0467 & 2.5235 & -0.0430 \\
\hline & $(-1.20)$ & $(2.18)$ & $(1.70)$ & $(-0.57)$ & $(0.84)$ & $(-0.34)$ \\
\hline \multirow[t]{2}{*}{ Price variation } & 0.0396 & 0.0359 & 0.0466 & 0.4127 & 0.1159 & -0.0095 \\
\hline & $(0.44)$ & $(1.46)$ & $(2.36)$ & $(0.62)$ & $(0.54)$ & $(-1.12)$ \\
\hline \multirow[t]{2}{*}{ Population } & 0.0205 & -0.0062 & -0.0041 & -0.5088 & -0.0229 & 0.0057 \\
\hline & $(0.65)$ & $(-0.76)$ & $(-0.58)$ & $(-2.07)$ & $(-0.40)$ & $(1.97)$ \\
\hline \multirow[t]{2}{*}{ Population growth } & 0.0084 & 0.0009 & -0.0005 & -0.0458 & 0.0010 & 0.0006 \\
\hline & $(1.52)$ & $(1.56)$ & $(-0.70)$ & $(-3.02)$ & $(0.06)$ & $(2.72)$ \\
\hline \multirow[t]{2}{*}{ Per capita income } & -0.0606 & 0.0105 & 0.0061 & 0.6837 & 0.0697 & -0.0030 \\
\hline & $(-1.63)$ & $(1.44)$ & $(0.99)$ & $(3.70)$ & $(1.33)$ & $(-1.19)$ \\
\hline \multirow[t]{2}{*}{ Income growth } & -0.0038 & 0.0001 & 0.0003 & -0.0096 & 0.0022 & -0.0001 \\
\hline & $(-2.51)$ & $(0.28)$ & $(0.58)$ & $(-1.16)$ & $(1.02)$ & $(-1.19)$ \\
\hline \multirow[t]{2}{*}{ Median home value } & -0.0191 & -0.0006 & -0.0005 & 0.0232 & -0.0195 & -0.0012 \\
\hline & $(-2.55)$ & $(-0.21)$ & $(-0.20)$ & $(0.32)$ & $(-1.23)$ & $(-1.09)$ \\
\hline \multirow[t]{2}{*}{ Home value growth } & -0.0175 & 0.0049 & 0.0008 & 0.1384 & -0.0403 & 0.0005 \\
\hline & $(-1.04)$ & $(1.24)$ & $(0.23)$ & $(1.13)$ & $(-1.06)$ & $(0.40)$ \\
\hline \multirow[t]{2}{*}{ Crime risk level } & 0.0002 & -0.0001 & -0.0002 & -0.0017 & -0.0004 & 0.0001 \\
\hline & $(1.55)$ & $(-1.63)$ & $(-1.24)$ & $(-1.70)$ & $(-1.74)$ & $(1.86)$ \\
\hline \multirow[t]{2}{*}{ Crime risk growth } & 0.1090 & -0.0180 & 0.0926 & 1.2362 & 0.7233 & -0.0103 \\
\hline & $(0.53)$ & $(-0.34)$ & $(2.06)$ & $(0.79)$ & $(1.66)$ & $(-0.55)$ \\
\hline \multicolumn{7}{|l|}{ Fixed effects? } \\
\hline County & yes & yes & yes & yes & yes & yes \\
\hline General zoning & yes & yes & yes & yes & yes & yes \\
\hline Property type & yes & yes & yes & yes & yes & yes \\
\hline Year & yes & yes & yes & yes & yes & yes \\
\hline Adjusted $R^{2}$ & 0.36 & 0.11 & 0.11 & 0.14 & 0.15 & 0.10 \\
\hline Adjusted $R^{2}$ (no F.E.) & 0.26 & 0.06 & 0.06 & 0.05 & 0.05 & 0.04 \\
\hline \# Observations & 3,536 & 9,365 & 7,733 & 7,733 & 1,971 & 7,733 \\
\hline \# Zip code clusters & 602 & 848 & 796 & 796 & 533 & 796 \\
\hline
\end{tabular}




\begin{tabular}{|c|c|c|c|c|c|c|}
\hline \multicolumn{7}{|c|}{ Panel B: Census tract fixed effects } \\
\hline Dependent variable $=$ & $\begin{array}{c}\text { Interest } \\
\text { rate }^{\dagger}\end{array}$ & $\begin{array}{c}\text { Debt } \\
\text { frequency }\end{array}$ & Leverage & $\begin{array}{c}\text { Debt } \\
\text { maturity }\end{array}$ & $\begin{array}{c}\text { Loan } \\
\text { duration }\end{array}$ & $\begin{array}{l}\text { Multiple } \\
\text { creditors }\end{array}$ \\
\hline Redeployability & -0.6213 & -0.0907 & 0.1365 & 6.6243 & 0.4001 & -0.0831 \\
\hline zoning intensity of use & $(-2.06)$ & $(-1.54)$ & $(2.41)$ & $(2.87)$ & $(2.46)$ & $(-1.97)$ \\
\hline $\log ($ size $)$ & -0.0949 & -0.0162 & & -1.0173 & -0.0203 & -0.0017 \\
\hline Cap rate (current value) & $\begin{array}{c}0.0133 \\
(2.57)\end{array}$ & $\begin{array}{l}0.0080 \\
(6.76)\end{array}$ & $\begin{array}{c}-0.0001 \\
(-0.34)\end{array}$ & $\begin{array}{l}0.0751 \\
(1.58)\end{array}$ & $\begin{array}{l}0.0099 \\
(1.98)\end{array}$ & $\begin{array}{c}-0.0028 \\
(-3.33)\end{array}$ \\
\hline $\log ($ age $)$ & $\begin{array}{c}0.0041 \\
(0.02)\end{array}$ & $\begin{array}{c}-0.0118 \\
(-2.10)\end{array}$ & $\begin{array}{c}-0.0123 \\
(-2.49)\end{array}$ & $\begin{array}{c}0.0836 \\
(0.39)\end{array}$ & $\begin{array}{c}-0.0200 \\
(-0.79)\end{array}$ & $\begin{array}{c}0.0135 \\
(3.45)\end{array}$ \\
\hline Fixed effects? & & & & & & \\
\hline Census tract & yes & yes & yes & yes & yes & yes \\
\hline General zoning & yes & yes & yes & yes & yes & yes \\
\hline Property type & yes & yes & yes & yes & yes & yes \\
\hline Year & yes & yes & yes & yes & yes & yes \\
\hline Adjusted $R^{2}$ & 0.38 & 0.11 & 0.11 & 0.16 & 0.25 & 0.13 \\
\hline Adjusted $R^{2}$ (no F.E.) & 0.26 & 0.06 & 0.06 & 0.05 & 0.05 & 0.04 \\
\hline
\end{tabular}

${ }^{\dagger}$ Includes an indicator for floating rates, loan size (relative to sale price), loan maturity, loan amortization, and an indicator for loans backed by the Small Business Administration.

Notes: Panel A reports regression results of the loan interest rate, frequency of debt, total leverage (ratio of debt to asset value, conditional on debt being present), debt maturity, loan duration (based on the loan amortization length and formula from equation 1) and the frequency of multiple creditors through second/subordinated debt contracts on a measure of real asset redeployability, using the allowable use of the property given by its zoning ordinance. Additional regressors include the $\log$ of the total sale price of the property (excluded from the loan-to-value regression), the capitalization rate of the property, which is the current earnings on the property divided by the sale price, the Herfindahl index of banking concentration within a 15 mile radius of the property, the log of property age, local price variation (cross-sectional variation of capitalization rates on properties within 5 miles of the property), the levels of population, per capita income, and median home value (all in logs) for the census tract in which the property resides (from the 1990 and 2000 Censuses) as well as the recent growth in population, income, and home value for the census tract from 1990 to 2000, and the current crime risk level and recent growth rate in crime risk for the property's location (obtained from CAP Index, Inc. for the crime index comprising the seven part one offenses of the FBI). The interest rate regressions also include the leverage ratio, an indicator for floating rates, an indicator for whether the loan is backed by the Small Business Administration (SBA), and the loan maturity and amortization as regressors (coefficients are not reported for brevity). Regressions include fixed effects for general zoning category, property type, year, and county. Coefficient estimates for the constant and fixed effects are not reported for brevity. Regressions are run under OLS with robust standard errors that assume group-wise clustering at the zip code level. Coefficient estimates and their associated $t$-statistics (in parentheses) are reported along with adjusted $R^{2}$ 's, including and excluding the fixed effects, and the number of observations and zip code clusters used to compute robust standard errors. Panel B repeats the regressions in Panel A using census tract fixed effects and excluding all variables measured at the census tract or coarser geographic level. 
Table 3:

Robustness of Redeployability (Measured by Zoning Intensity of Use) to Additional Controls for Current Value

\begin{tabular}{|c|c|c|c|c|c|c|}
\hline Dependent variable $=$ & $\begin{array}{l}\text { Interest } \\
\text { rate }\end{array}$ & $\begin{array}{c}\text { Debt } \\
\text { frequency }\end{array}$ & Leverage $^{\dagger}$ & $\begin{array}{c}\text { Debt } \\
\text { maturity }\end{array}$ & $\begin{array}{l}\text { Loan } \\
\text { duration }\end{array}$ & $\begin{array}{l}\text { Multiple } \\
\text { creditors }\end{array}$ \\
\hline \multicolumn{7}{|c|}{$\begin{array}{l}\text { (1) Controlling for: } \log (\text { sale price), cap rate (current value), and interactions of cap rate with } \\
\text { zoning category and property type. }\end{array}$} \\
\hline \multicolumn{7}{|c|}{ Panel A of Table 2: Local economic and social controls } \\
\hline Redeployability & $\begin{array}{c}-0.4606 \\
(-2.28)\end{array}$ & $\begin{array}{c}0.1204 \\
(2.42)\end{array}$ & $\begin{array}{c}0.1475 \\
(3.22)\end{array}$ & $\begin{array}{l}3.7785 \\
(2.25)\end{array}$ & $\begin{array}{c}0.7753 \\
(2.02)\end{array}$ & $\begin{array}{r}-0.0417 \\
(-1.92)\end{array}$ \\
\hline \multicolumn{7}{|c|}{ Panel B of Table 2: Census tract fixed effects } \\
\hline Redeployability & $\begin{array}{c}-0.6047 \\
(-2.00)\end{array}$ & $\begin{array}{l}-0.0965 \\
(-1.62)\end{array}$ & $\begin{array}{c}0.1403 \\
(2.46)\end{array}$ & $\begin{array}{l}7.0316 \\
(3.01)\end{array}$ & $\begin{array}{c}0.8001 \\
(2.46)\end{array}$ & $\begin{array}{c}-0.0782 \\
(-1.82)\end{array}$ \\
\hline
\end{tabular}

(2) Controlling for: $\log$ (sale price), cap rate, and interactions of cap rate and sale price with zoning category and property type.

Panel A of Table 2: Local economic and social controls

Redeployability $\quad-0.4709 \quad 0.1089$

$$
(-2.27) \quad(2.19)
$$

3.3949

0.7358

$-0.0417$

Panel B of Table 2: Census tract fixed effects

$\begin{array}{lllllll}\text { Redeployability } & -0.6196 & -0.0771 & 0.1403 & 7.4815 & 0.7917 & -0.0784 \\ & (-2.04) & (-1.28) & (2.46) & (3.17) & (2.55) & (-1.78)\end{array}$

(3) Controlling for: $\log$ (sale price), $\log (\text { sale price })^{2}, \log (\text { sale price })^{3}$, cap rate, cap rate ${ }^{2}$, cap rate $^{3}$, and interactions of cap rate and sale price with zoning category and property type. Panel A of Table 2: Local economic and social controls
Redeployability
$-0.4826 \quad 0.0987$
0.1450
3.1373
0.7204
$-0.0447$
Panel B of Table 2: Census tract fixed effects

\begin{tabular}{lcccccc} 
Redeployability & -0.6399 & -0.0791 & 0.1422 & 7.5363 & 0.7706 & -0.0786 \\
& $(-2.11)$ & $(-1.32)$ & $(2.48)$ & $(3.19)$ & $(3.00)$ & $(-1.78)$ \\
\hline
\end{tabular}

\footnotetext{
$\dagger$ Excludes all size variables since the dependent variable is the amount of debt scaled by size (sale price).

Notes: The robustness of the regression results from Table 2 to various specifications for controlling for current value are reported. Three different specifications for controlling for the current value of the property using current price, earnings, and capitalization rates on the property and their interactions with property type and zoning categorical dummies are employed. The first row of each specification includes the same regressors as Panel A of Table 2 to control for local economic and social activity including fixed effects for general zoning category, property type, year, and county. Regressions are run under OLS with robust standard errors that assume group-wise clustering at the zip code level. The second row of each specification includes the same regressors as Panel B of Table 2 which includes census tract fixed effects and is also run under OLS. For brevity, only the coefficient estimate and associated $t$-statistic (in parentheses) on the redeployability measure (zoning intensity of use) is reported.
} 
Table 4:

Cross-Sectional Evidence on Redeployability Affecting Debt Contracts

\begin{tabular}{|c|c|c|c|c|c|c|}
\hline Dependent variable $=$ & $\begin{array}{l}\text { Interest } \\
\text { rate }\end{array}$ & $\begin{array}{c}\text { Debt } \\
\text { frequency }\end{array}$ & Leverage & $\begin{array}{c}\text { Debt } \\
\text { maturity }\end{array}$ & $\begin{array}{c}\text { Loan } \\
\text { duration }\end{array}$ & $\begin{array}{l}\text { Multiple } \\
\text { creditors }\end{array}$ \\
\hline \multicolumn{7}{|c|}{ Panel A: Interactions with strictness of zoning } \\
\hline Redeployability & $\begin{array}{c}0.4237 \\
(0.40)\end{array}$ & $\begin{array}{r}-0.4111 \\
(-2.06)\end{array}$ & $\begin{array}{c}-0.5417 \\
(-2.36)\end{array}$ & $\begin{array}{c}-24.5356 \\
(-1.92)\end{array}$ & $\begin{array}{l}0.8227 \\
(1.96)\end{array}$ & $\begin{array}{l}1.1032 \\
(3.58)\end{array}$ \\
\hline Zoning strictness index & $\begin{array}{c}0.6273 \\
(0.69)\end{array}$ & $\begin{array}{c}-0.1174 \\
(-0.26)\end{array}$ & $\begin{array}{c}-0.1748 \\
(-0.38)\end{array}$ & $\begin{array}{c}-25.3957 \\
(-2.24)\end{array}$ & $\begin{array}{c}-0.0022 \\
(-1.37)\end{array}$ & $\begin{array}{c}0.2470 \\
(0.45)\end{array}$ \\
\hline Redeployability $\times$ zoning strictness & $\begin{array}{c}-0.4091 \\
(-1.82)\end{array}$ & $\begin{array}{c}0.2252 \\
(2.42)\end{array}$ & $\begin{array}{l}0.3222 \\
(3.08)\end{array}$ & $\begin{array}{c}12.3838 \\
(2.40)\end{array}$ & $\begin{array}{l}0.0012 \\
(2.25)\end{array}$ & $\begin{array}{c}-0.5189 \\
(-3.35)\end{array}$ \\
\hline Redeployability & $\begin{array}{c}5.4375 \\
(3.56)\end{array}$ & $\begin{array}{l}-0.4952 \\
(-1.82)\end{array}$ & $\begin{array}{c}-0.9007 \\
(-1.65)\end{array}$ & $\begin{array}{c}-13.8488 \\
(-0.35)\end{array}$ & $\begin{array}{l}0.8181 \\
(1.98)\end{array}$ & $\begin{array}{c}0.7939 \\
(0.88)\end{array}$ \\
\hline Growth management index & $\begin{array}{c}0.2033 \\
(0.93)\end{array}$ & $\begin{array}{l}0.0431 \\
(0.32)\end{array}$ & $\begin{array}{c}-0.1205 \\
(-1.36)\end{array}$ & $\begin{array}{r}-4.0841 \\
(-1.39)\end{array}$ & $\begin{array}{c}-0.0021 \\
(-1.37)\end{array}$ & $\begin{array}{l}0.1699 \\
(1.28)\end{array}$ \\
\hline Redeployability $\times$ growth management & $\begin{array}{c}-1.3251 \\
(-3.86)\end{array}$ & $\begin{array}{l}0.1245 \\
(1.99)\end{array}$ & $\begin{array}{l}0.2606 \\
(1.96)\end{array}$ & $\begin{array}{l}3.4291 \\
(2.14)\end{array}$ & $\begin{array}{l}0.0011 \\
(2.24)\end{array}$ & $\begin{array}{c}-0.1682 \\
(-1.89)\end{array}$ \\
\hline Redeployability & $\begin{array}{c}0.8540 \\
(1.88)\end{array}$ & $\begin{array}{c}-0.1205 \\
(-1.31)\end{array}$ & $\begin{array}{c}-0.0996 \\
(-0.80)\end{array}$ & $\begin{array}{c}-3.6482 \\
(-0.83)\end{array}$ & $\begin{array}{c}0.6445 \\
(1.69)\end{array}$ & $\begin{array}{c}0.2027 \\
(1.56)\end{array}$ \\
\hline Historic & $\begin{array}{l}0.5197 \\
(1.74)\end{array}$ & $\begin{array}{l}0.0225 \\
(0.26)\end{array}$ & $\begin{array}{c}-0.1236 \\
(-1.30)\end{array}$ & $\begin{array}{l}4.9454 \\
(0.99)\end{array}$ & $\begin{array}{c}-0.2323 \\
(-1.24)\end{array}$ & $\begin{array}{c}-0.0223 \\
(-0.16)\end{array}$ \\
\hline Redeployability $\times$ historic & $\begin{array}{c}-1.9869 \\
(-3.84)\end{array}$ & $\begin{array}{l}0.2219 \\
(2.03)\end{array}$ & $\begin{array}{c}0.3050 \\
(2.26)\end{array}$ & $\begin{array}{c}11.2079 \\
(2.17)\end{array}$ & $\begin{array}{l}0.3075 \\
(0.59)\end{array}$ & $\begin{array}{c}-0.3126 \\
(-2.02)\end{array}$ \\
\hline Redeployability & $\begin{array}{c}0.3299 \\
(1.42)\end{array}$ & $\begin{array}{c}-0.1046 \\
(-2.47)\end{array}$ & $\begin{array}{c}-0.0596 \\
(-1.29)\end{array}$ & $\begin{array}{l}-9.5892 \\
(-4.79)\end{array}$ & $\begin{array}{l}0.2988 \\
(1.52)\end{array}$ & $\begin{array}{c}0.0421 \\
(1.60)\end{array}$ \\
\hline $\begin{array}{l}\text { Zoning concentration } \\
\text { within zip code }\end{array}$ & $\begin{array}{c}-0.2398 \\
(-1.08)\end{array}$ & $\begin{array}{l}-0.0064 \\
(-0.15)\end{array}$ & $\begin{array}{c}-0.0345 \\
(-0.76)\end{array}$ & $\begin{array}{r}-7.4457 \\
(-3.62)\end{array}$ & $\begin{array}{l}0.0415 \\
(0.99)\end{array}$ & $\begin{array}{c}0.0423 \\
(1.64)\end{array}$ \\
\hline Redeployability $\times$ zoning concentration & $\begin{array}{c}-0.0709 \\
(-0.18)\end{array}$ & $\begin{array}{c}0.1452 \\
(1.92)\end{array}$ & $\begin{array}{c}0.1678 \\
(2.16)\end{array}$ & $\begin{array}{c}16.5203 \\
(4.52)\end{array}$ & $\begin{array}{c}0.0168 \\
(2.12)\end{array}$ & $\begin{array}{c}-0.1002 \\
(-2.28)\end{array}$ \\
\hline \multicolumn{7}{|c|}{ Panel B: Interactions with enforcement of law } \\
\hline Redeployability & $\begin{array}{l}4.6329 \\
(3.46)\end{array}$ & $\begin{array}{c}-0.5127 \\
(-2.02)\end{array}$ & $\begin{array}{c}-0.6944 \\
(-2.59)\end{array}$ & $\begin{array}{c}-56.0970 \\
(-3.64)\end{array}$ & $\begin{array}{c}-0.8020 \\
(-1.16)\end{array}$ & $\begin{array}{c}0.8804 \\
(2.02)\end{array}$ \\
\hline \#Arresting officers per capita & $\begin{array}{c}-0.0254 \\
(-0.40)\end{array}$ & $\begin{array}{c}-0.0735 \\
(-1.29)\end{array}$ & $\begin{array}{c}-0.1091 \\
(-3.80)\end{array}$ & $\begin{array}{c}-4.1719 \\
(-2.48)\end{array}$ & $\begin{array}{l}-0.0581 \\
(-0.75)\end{array}$ & $\begin{array}{c}0.1486 \\
(3.00)\end{array}$ \\
\hline Redeployability $\times \#$ arresting officers & $\begin{array}{c}-0.6090 \\
(-3.74)\end{array}$ & $\begin{array}{c}0.0799 \\
(2.54)\end{array}$ & $\begin{array}{c}0.1114 \\
(3.45)\end{array}$ & $\begin{array}{l}7.1704 \\
(4.03)\end{array}$ & $\begin{array}{l}0.2245 \\
(2.48)\end{array}$ & $\begin{array}{c}-0.1298 \\
(-2.42)\end{array}$ \\
\hline Redeployability & $\begin{array}{c}-0.4269 \\
(-1.84)\end{array}$ & $\begin{array}{c}0.1273 \\
(2.91)\end{array}$ & $\begin{array}{c}0.1993 \\
(3.78)\end{array}$ & $\begin{array}{c}3.1544 \\
(1.31)\end{array}$ & $\begin{array}{l}0.7508 \\
(2.21)\end{array}$ & $\begin{array}{c}-0.1777 \\
(-1.89)\end{array}$ \\
\hline \#Federal corruption convictions per capita & $\begin{array}{c}-0.0027 \\
(-1.32)\end{array}$ & $\begin{array}{l}0.0012 \\
(2.35)\end{array}$ & $\begin{array}{l}0.0004 \\
(0.71)\end{array}$ & $\begin{array}{l}0.0236 \\
(1.18)\end{array}$ & $\begin{array}{c}-0.0029 \\
(-0.78)\end{array}$ & $\begin{array}{c}-0.0011 \\
(-1.34)\end{array}$ \\
\hline Redeployability $\times$ \#corruption convictions & $\begin{array}{c}0.0174 \\
(2.27)\end{array}$ & $\begin{array}{c}-0.0036 \\
(-1.56) \\
\end{array}$ & $\begin{array}{l}0.0012 \\
(0.40)\end{array}$ & $\begin{array}{c}-0.1580 \\
(-1.63)\end{array}$ & $\begin{array}{c}-0.0066 \\
(-0.52) \\
\end{array}$ & $\begin{array}{l}0.0014 \\
(0.39)\end{array}$ \\
\hline
\end{tabular}




\begin{tabular}{lcccccc}
\hline \multirow{2}{*}{ Dependent variable $=$} & $\begin{array}{c}\text { Interest } \\
\text { rate }\end{array}$ & $\begin{array}{c}\text { Debt } \\
\text { frequency }\end{array}$ & Leverage & $\begin{array}{c}\text { Debt } \\
\text { maturity }\end{array}$ & $\begin{array}{c}\text { Loan } \\
\text { duration }\end{array}$ & $\begin{array}{c}\text { Multiple } \\
\text { creditors }\end{array}$ \\
\hline \multirow{3}{*}{ Redeployability } & Panel C: Interactions & with local & market liquidity & & \\
& 1.0033 & -0.2813 & -0.1923 & -11.7964 & 0.8275 & 0.4413 \\
Demand-to-supply & $(1.52)$ & $(-2.37)$ & $(-1.46)$ & $(-1.65)$ & $(1.97)$ & $(2.50)$ \\
& 0.0216 & -0.1482 & -0.0809 & -4.3920 & -0.0022 & 0.2684 \\
Redeployability $\times$ demand-to-supply & $(0.09)$ & $(-1.11)$ & $(-0.90)$ & $(-1.43)$ & $(-1.39)$ & $(2.19)$ \\
& -0.5855 & 0.1451 & 0.1359 & 5.7006 & 0.0013 & -0.1811 \\
& $(-2.34)$ & $(3.25)$ & $(2.72)$ & $(2.42)$ & $(0.27)$ & $(-2.26)$ \\
Redeployability & & & & & & \\
& -0.9558 & 0.2829 & 0.3785 & 16.0872 & 1.2165 & -0.5219 \\
Broker Herfindahl & $(-2.04)$ & $(3.93)$ & $(3.70)$ & $(3.70)$ & $(2.38)$ & $(-2.81)$ \\
& 0.1127 & 0.6327 & 1.2790 & 30.2941 & 1.5040 & -2.9041 \\
Redeployability $\times$ broker Herfindahl & $(0.04)$ & $(2.06)$ & $(2.65)$ & $(1.26)$ & $(0.44)$ & $(-3.33)$ \\
& 12.6525 & -3.4476 & -3.5324 & -292.3673 & -7.7877 & 7.3109 \\
& $(1.47)$ & $(-3.01)$ & $(-2.00)$ & $(-3.36)$ & $(-1.31)$ & $(2.15)$ \\
\hline
\end{tabular}

Notes: Regression results of the loan interest rate, frequency of debt, total leverage, debt maturity, loan duration, and frequency of multiple creditors on asset redeployability (measured by the intensity of allowable property use from the property's zoning ordinance) and its interaction with characteritics of the local market in which the property resides are reported. Panel A examines interactions with variables designed to capture the strictness of zoning. The first is an index of zoning strictness which is the average of the following two measures from the Wharton Land Use Control Survey under the Wharton Urban Decentralization Project (see Glaeser and Gyourko (2002)): the percentage of applications for zoning changes that were approved in the local MSA during 1989, and the estimated number of months between application for rezoning and issuance of a building permit for the development of a property in the MSA (average for single family units and office buildings). The second measure is an index of the effectiveness of growth management techniques employed in the MSA obtained from the Wharton Land Use Control Survey. Specifically, survey respondents assessment of the effectiveness of ordinances, building permits, and zoning ordinances in controlling growth are provided on a scale of 1 (not important) to 5 (very important) and the average across the three categories is the growth management index. The third measure of zoning strictness is an indicator variable for properties with an historic zoning designation. The fourth measure is the similarity of zoning ordinances on surrounding properties (zoning concentration), which is the fraction of properties in the same zip code that have the same general zoning designation. Panel B examines interactions with variables proxying for the enforcement of law: the number of arresting officers per capita in the county in which the property resides (obtained from the FBI from 1992 to 1999), and the number of federal public corruption convictions per capita for the state in which the property resides (obtained from the Department of Justice from 1992 to 1999). Panel C examines interactions with measures of local market liquidity. The first is the average of the quantitative ratings of survey respondents from the Wharton Land Use Control Survey on the ratio of demand for land uses relative to the acreage of land zoned for those uses across single family, multi-family, commercial, and industrial uses, and across various lot sizes. The second measure of market liquidity is the Herfindahl concentration index of property brokers within a 5 mile radius of the property. All regressions include the regressors from Table 2, including fixed effects for general zoning category, property type, county, and year as well as a constant, where robust standard errors are computed assuming group-wise clustering at the MSA (for Wharton Land Use Control Survey data) or zip code (for all other data) level. Appendix B details the sources and computations of all relevant variables. 
Table 5:

Other Measures of Liquidation Value and Their Relation to Debt Contracts

\begin{tabular}{|c|c|c|c|c|c|c|}
\hline Dependent variable $=$ & $\begin{array}{c}\text { Interest } \\
\text { rate }\end{array}$ & $\begin{array}{c}\text { Debt } \\
\text { frequency }\end{array}$ & Leverage & $\begin{array}{c}\text { Debt } \\
\text { maturity }\end{array}$ & $\begin{array}{c}\text { Loan } \\
\text { duration }\end{array}$ & $\begin{array}{l}\text { Multiple } \\
\text { creditors }\end{array}$ \\
\hline \multicolumn{7}{|c|}{ Panel A: Local economic and social controls (from Table 2 Panel A) } \\
\hline Broker Herfindahl & $\begin{array}{l}1.1545 \\
(1.88)\end{array}$ & $\begin{array}{c}-0.1584 \\
(-2.15)\end{array}$ & $\begin{array}{c}-0.0103 \\
(-0.12)\end{array}$ & $\begin{array}{c}-5.0265 \\
(-2.70)\end{array}$ & $\begin{array}{c}-3.3871 \\
(-0.62)\end{array}$ & $\begin{array}{c}-0.6806 \\
(-1.94)\end{array}$ \\
\hline Historic & $\begin{array}{c}0.3268 \\
(2.30)\end{array}$ & $\begin{array}{c}-0.0516 \\
(-2.05)\end{array}$ & $\begin{array}{c}-0.0363 \\
(-1.74)\end{array}$ & $\begin{array}{c}-3.1052 \\
(-1.77)\end{array}$ & $\begin{array}{c}-0.0784 \\
(-0.93)\end{array}$ & $\begin{array}{c}-0.1136 \\
(-0.86)\end{array}$ \\
\hline $\begin{array}{l}\text { Local volume } \\
\text { within zip code }\end{array}$ & $\begin{array}{c}-0.0015 \\
(-0.73)\end{array}$ & $\begin{array}{l}0.0010 \\
(1.96)\end{array}$ & $\begin{array}{l}0.0008 \\
(4.04)\end{array}$ & $\begin{array}{l}0.0636 \\
(2.54)\end{array}$ & $\begin{array}{l}0.0050 \\
(0.52)\end{array}$ & $\begin{array}{c}-0.0030 \\
(-2.92)\end{array}$ \\
\hline $\begin{array}{l}\text { Zoning concentration } \\
\text { within zip code }\end{array}$ & $\begin{array}{c}-0.1583 \\
(-1.82)\end{array}$ & $\begin{array}{l}0.0651 \\
(3.65)\end{array}$ & $\begin{array}{l}0.0154 \\
(1.79)\end{array}$ & $\begin{array}{l}1.5008 \\
(2.05)\end{array}$ & $\begin{array}{c}-0.1055 \\
(-0.31)\end{array}$ & $\begin{array}{c}-0.0444 \\
(-1.57)\end{array}$ \\
\hline Population radius & $\begin{array}{c}-0.0262 \\
(-0.62)\end{array}$ & $\begin{array}{r}-0.0440 \\
(-4.89)\end{array}$ & $\begin{array}{c}-0.0081 \\
(-2.12)\end{array}$ & $\begin{array}{c}-0.1910 \\
(-0.43)\end{array}$ & $\begin{array}{l}0.1371 \\
(0.71)\end{array}$ & $\begin{array}{c}0.0315 \\
(2.17)\end{array}$ \\
\hline Age $>30$ & $\begin{array}{c}-0.0165 \\
(-0.48)\end{array}$ & $\begin{array}{c}-0.0356 \\
(-4.42)\end{array}$ & $\begin{array}{c}0.0048 \\
(1.40)\end{array}$ & $\begin{array}{c}-0.6675 \\
(-2.02)\end{array}$ & $\begin{array}{c}-0.4796 \\
(-2.10)\end{array}$ & $\begin{array}{c}0.1326 \\
(8.61)\end{array}$ \\
\hline \multicolumn{7}{|c|}{ Panel B: Census tract fixed effects (from Table 2 Panel B) } \\
\hline Historic & $\begin{array}{c}0.5913 \\
(3.17)\end{array}$ & $\begin{array}{c}-0.1085 \\
(-2.27)\end{array}$ & $\begin{array}{c}-0.0490 \\
(-2.17)\end{array}$ & $\begin{array}{c}-0.4942 \\
(-0.39)\end{array}$ & $\begin{array}{c}-0.1109 \\
(-1.93)\end{array}$ & $\begin{array}{l}0.1187 \\
(2.49)\end{array}$ \\
\hline Age $>30$ & $\begin{array}{c}-0.0208 \\
(-0.49)\end{array}$ & $\begin{array}{r}-0.0319 \\
(-3.92)\end{array}$ & $\begin{array}{l}0.0083 \\
(2.09)\end{array}$ & $\begin{array}{c}-0.6315 \\
(-1.93)\end{array}$ & $\begin{array}{c}-0.4596 \\
(-2.79)\end{array}$ & $\begin{array}{l}0.1108 \\
(8.95)\end{array}$ \\
\hline
\end{tabular}

Notes: Regression results of the loan interest rate, frequency of debt, total leverage, debt maturity, loan duration, and frequency of multiple creditors on other measures of asset liquidation value are reported. The first measure is the Herfindahl concentration index of property brokers within a 5 mile radius of the property. The second measure is an indicator variable for properties with an historic zoning designation. The third measure is the local volume or the number of sales of properties within the same zip code. The fourth measure is the similarity of a property's zoning classification to that of surrounding properties, namely the fraction of properties within the zip code that have the same general zoning designation (zoning concentration). The fifth measure is the population density radius (defined as the minimum of the radius surrounding the property which encompasses 100,000 people or 3 miles). The final measure of liquidation value is a dummy for properties older than 30 years. Regressions in Panel A include the local economic control variables from Table 2 Panel A as regressors, including fixed effects for general zoning category, property type, year, and county. Regressions in Panel B include census tract fixed effects and the remaining regressors from Table 2 Panel B. Robust standard errors are computed assuming group-wise clustering at the zip code level in Panel A. Coefficient estimates and their associated $t$-statistics (in parentheses) are reported. 
Table 6:

The Relation Between Asset Redeployability, Prices, and Broker Activity

\begin{tabular}{lccc}
\hline Dependent & & & Probability of \\
Variable $=$ & $\log ($ Sale price $)$ & $\log ($ Sale price $)-\log ($ Earnings $)$ & Hiring a broker \\
\hline \multicolumn{2}{c}{ Panel A: Local economic and social controls (from Table 2 Panel A) } \\
Redeployability & 0.9313 & 1.0823 & -0.0310 \\
& $(6.88)$ & $(10.84)$ & $(-3.89)$ \\
\multicolumn{5}{c}{ Panel B: Census tract fixed effects (from Table 2 Panel B) } \\
Redeployability & 0.9208 & 1.0042 & -0.0210 \\
& $(11.41)$ & $(9.98)$ & $(-3.37)$ \\
\hline
\end{tabular}

Notes: The table reports regression results of various measures of liquidation value, demand and supply on the redeployability measure (zoning flexibility). Specifically, the log of the sale price (controlling for current earnings on the property), and probability of hiring a broker (controlling for the concentration of brokers in the local area), are regressed on the redeployability measure zoning flexibility. The first two columns contain the sale price results where the first column regresses the log of the sale price on redeployability and log of current earnings and the second column regresses the log of the sale price minus the log of earnings on redeployability (i.e., forcing the coefficient on $\log$ (earnings) to be 1). Regressions in Panel A include the regressors from Table 2 Panel A, including fixed effects for general zoning category, property type, year, and county as well as a constant and robust standard errors are computed assuming group-wise clustering at the zip code level. The broker regression also includes the Herfindahl concentration index of broker activity within a 5 mile radius of the property. Regressions in Panel B include census tract fixed effects and the remaining regressors from Table 2 Panel B. For brevity, only the coefficient estimate (and $t$-statistic in parentheses) on redeployability is reported in both panels. 
Figure 1

\section{Distribution of Redeployability (Zoning Flexibility)}

The distribution of a measure of real asset liquidation value determined by a proxy for the asset's redeployability measured by its zoning ordinance is plotted below. The allowable use of the property within its broad zoning category and local zoning jurisdiction, scaled by the maximum allowable uses within an area and zoning category, is the measure of redeployability. Higher values indicate broader scopes of allowable uses within a general category and jurisdiction.

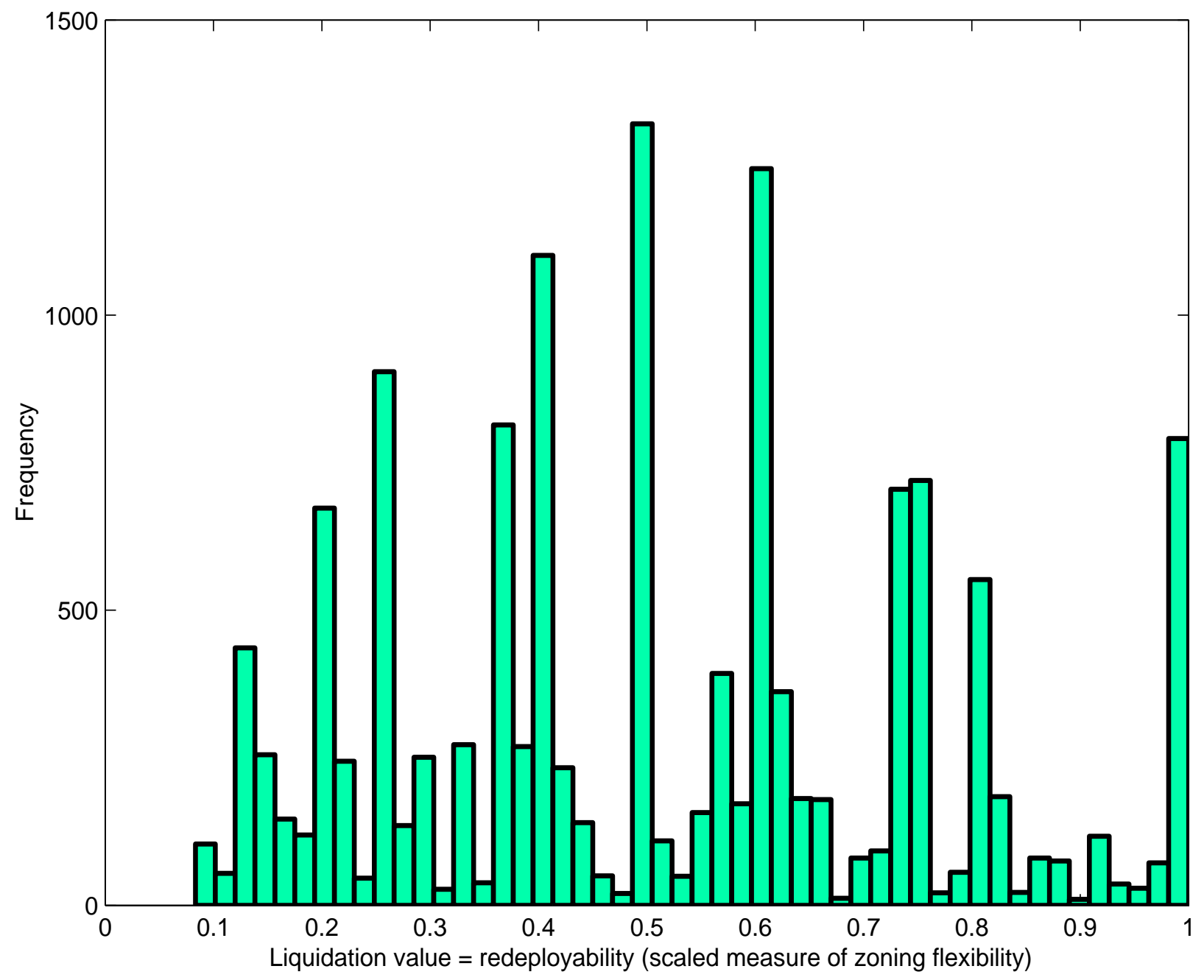

Summary statistics of the liquidation value measure standard

\begin{tabular}{llllll} 
& mean & median & deviation & minimum & maximum \\
\cline { 2 - 6 } Redeployability & 0.51 & 0.50 & 0.24 & 0.08 & 1 \\
\hline
\end{tabular}

